\title{
A REVISION OF THE GENUS MICRORHOPALA (COLEOPTERA: CHRYSOMELIDAE) IN AMERICA NORTH OF MEXICO
}

\author{
Shawn M. Clark
}

\begin{abstract}
The eight known North American species of Microrhopala infest Solidago, Aster, and other compositaceous plants. Descriptions and keys to species and subspecies are given. Microrhopala rileyi is named as a new species from Missouri, $M$. hecate (Newman) is removed from synonymy with $M$. cyanea (Say), and $M$. cyanea is reduced to a subspecies of M. excavata (Olivier). Lectotypes are designated for taxa described originally in the genus Hispa, i.e., Hispa vittata, H. xerene, and $H$. erebus, and neotypes are designated for $H$. excavata and $H$. cyanea. Phylogenetic relationships are discussed.
\end{abstract}

History.- The generic name Microrhopala was first published by Dejean (1837) and attributed to Chevrolat. This name has often been listed with Dejean as its author, because it was never actually described or listed by Chevrolat. However, following the nomenclatural interpretation of Barber and Bridwell (1940), authorship is again credited to Chevrolat in this study. Included in the genus were two valid species, Hispa vittata Fabricius, 1798, and H. excavata Olivier, 1808.

Melsheimer (1853) added H. cyanea Say, 1823 , to the genus but referred $H$. excavata back to Hispa. Baly (1864) published the first generic description of Microrhopala and designated $H$. vittata as the type species. He also returned $H$. excavata to the genus and added H. xerene Newman, 1838. Odontota rubrolineata Mannerheim, 1843, was transferred to the genus by Crotch (1873), and, finally, Schwarz (1878) named M. floridana and also transferred $H$. erebus Newman, 1841, to the genus. Several other species are known from tropical America but do not extend north of Mexico; no Old World species are known.

In addition to the species cited above, several varieties and geographical races have been named in Microrhopala. LeConte (1859a) presented $M$. signaticollis as a distinct species, but it was reduced to a variety of rubrolineata by Crotch (1873). Microrhopala xerene var. interrupta was named by Couper
(1865). Horn (1883) presented M. vulnerata as a distinct species, but this was reduced to a variety of rubrolireata by Weise (1911). Finally, M. rubrolineata var. militaris was named by Van Dyke (1925). Most of these varieties represent true subspecies, but laetula and interrupta are no longer recognized (Weise 1911, McCauley 1938).

Also, $H$. hecate Newman, 1841, was synonymized with $M$. cyanea by Gemminger and Harold (1876), and M. bivitticollis was described by Baly (1864) and later synonymized with $M$. rubrolineata var. signaticollis by Weise (1911).

In addition to the above species that actually belong to Microrhopala, various others have sometimes been assigned to the genus but do not belong here. These are $M$. porcata (Melsheimer, 1846) (now in Glyphuroplata), M. collaris (Say, 1823) (now in Chalepus and synonymized with C. walshi), M. melsheimeri Crotch, 1873 (now in Brachycoryna and synonymized with B. hardyi), M. plicatula (Fabricius, 1801) (now in Octotoma), M. uniformis Smith, 1885 (now in Uroplata), M. dimidiata Horn, 1883 (now in Pentispa and synonymized with $P$. melanura), M. montana Horn, 1883 (now in Brachycoryna), M. suturalis (Baly, 1885) (now in Pentispa), and M. arizonica Schaeffer, 1906 (now in Pentispa and synonymized with $P$. suturalis).

Relationship to Other Genera.- Within the family Chrysomelidae, Microrhopala is

'Department of Zoology, Brigham Young University, Provo, Utah 84602. Present address: Department of Entomology, Ohio State University, Columbus, Ohio 43210. 
placed in the subfamily Hispinae and the tribe Uroplatini (Weise 1910). The tribe Uroplatini is best characterized by having the four terminal segments of the antenna very closely united and often appearing as a single segment.

In addition to Microrhopala, five other genera are included in this tribe. Four of these genera-Octotoma, Brachycoryna, Stenopodius, and Glyphuroplata-are easily distinguished from Microrhopala as follows. Brachycoryna and Stenopodius are distinguished from the others by their short antennae that are not longer than the pronotum, and Octotoma and Glyphuroplata are distinguished by having more than eight striae on the elytra. Apart from being members of the same tribe, these genera show no particularly close affinities to Microrhopala. However, the fifth genus, Pentispa, shares many characters with Microrhopala and is apparently closely related. It is distinguished by the flattened, more strongly costate elytra, but even this character does not eliminate all difficulties in separating the genera. In fact, a careful study of the species of Pentispa may eventually indicate that they are congeneric.

\section{Biology}

The life cycle and development of Microrhopala are well known for only $M$. vittata and M. xerene (Hendrickson 1930, McCauley 1938). During the summers of 1980 and 1981, I observed these two species in Provo Canyon, Utah, and confirmed previous reports about them, but also uncovered new information. These data summarize what is known about vittata and xerene, but much of it probably applies to the other species in this genus.

So far as is known, larvae of all species in the genus are internal leaf miners of compositaceous plants, and adults are external leaf feeders of the same host species. Host selection is very narrow, and each beetle species is restricted in its feeding activity to only a few plant species.

Oviposition occurs in the early summer and may be either on the upper or lower surface of the host leaf, usually near the apex. A female usually lays three to five disk-shaped eggs in a contiguous row. The eggs are positioned on their edges and are slightly tilted back on each other. After oviposition, the female covers the eggs with an anal secretion, likely feces, that soon hardens to a black, crusty material, which probably serves to protect the eggs. Often, several rows of eggs are laid alongside one another, in which case all rows are protected by a single covering. I observed a female of $M$. vittata laying eggs on 16 June 1981; these eggs hatched on 10 July 1981, thus indicating a period of 3.5 weeks ( 25 days) in this stage of development.

When the eggs hatch, the larvae enter directly into the leaves below the crusty covering without exposing themselves to the external environment and begin feeding on tissues between the upper and lower epidermal layers. Mining begins near the apex of the leaf and continues to the base. I have seen larvae of $M$. xerene emerge from one leaf and enter another, where mining activity continued. Eventually, the larvae dispersed themselves such that only one to four larvae were usually found in each leaf. In 1981 I noted that the first eggs of $M$. vittata hatched on 23 June, and pupae were first noted on 22 July, thus indicating a larval duration of approximately one month (30 days).

At the end of the larval stage many leaves contain large, inflated cavities where the larvae have mined. The beetles pupate in these cavities. According to my observations, the pupal period lasts for five to eight days.

The adults emerge and spend several days within the mines until their cuticle is sufficiently hardened. They then abandon the mines and begin to feed externally on the same host as did the larvae. Small areas of the leaf, usually not much larger than the size of a beetle, are skeletonized by this activity. After feeding, a few beetles mate. However, most mating activity is delayed until the next spring.

Toward the end of the summer, the beetles begin to wander, presumably in search of places to pass the winter. During this time they may be found on many plant species, but they do not feed on them, and this has likely led to several erroneous host plant records. Eventually, the beetles find areas under loose bark, crevices in the soil, accumulated debris, or leaf litter, and pass the winter in these situations. 
When spring arrives, the beetles emerge from their overwintering sites, then resume feeding and mating activity. Males remain mounted atop females for several hours before copulation actually takes place. I have observed such pairs of $M$. vittata rapidly swaying from side to side in repeated motions that continue for up to one minute. The motions may be important in identifying a mate, and it is possible that comparable activities may exist for other species. Eventually, copulation occurs, and oviposition begins within a few days. In 1981, I observed that a population of $M$. vittata first laid eggs on 26 May and continued until 22 July, indicating an oviposition period of just less than two months. Soon after oviposition the adults died. Nearly all the beetles died before the next generation of adults emerged.

Generally, only one generation is produced each year, but there is some indication that there may be two generations at low altitudes in the southern United States. Also, adults can be found throughout the year but are most often collected only during the active summer months.

\section{Discussion of Characters}

Various characters have been used in the classification of Microrhopala (Baly 1864,
Douglass 1929, McCauley 1938). These include the presence or absence of costae on the elytra, the size of serrations on interstriae 9 , the size and depth of pronotal and elytral punctures, the color, the presence or absence of metallic lusters, and the size and conformation of colored markings when present.

McCauley (1938) attempted to find reliable genitalic characters but reported the following:

The genitalia of Microrhopala in common with other genera of the subfamily Hispinae are of little taxonomic value. During the winter of 1935-1936 the male genital tubes of a large series of individuals from all of the species in the genus were carefully dissected out and mounted upon hairs. The results were very disappointing. At first, slight differences seemed to be apparent between species, but as the series were extended it was soon obvious that these differences were no greater than the differences existing between members of what were unquestionably the same species. In no instance was a character observed which was either constant, distinct, or describable enough to be used taxonomically. The female genitalia showed even less and in addition are difficult to preserve in a position undistorted as well as practical for observation.

In connection with the present study, all the characters mentioned above were again examined, and several others were also investigated (Table 1). These previously unused characters include the extent of minute reticulation, the size of the eye, the nature of the punctures behind the eye, the shape of the

TABLE 1. Ancestral and derived characters of Microrhopala.

Ancestral

1. Mesal impression of vertex not laterally margined by punctures

2. Elytra with more than eight striae

3. Eye large

4. Thin strip of cuticle at anterior margin of pronotum well formed

5. Ventral area of head not reticulate

6. Red markings present

7. Femora broad

8. Interstriae 9 strongly serrate

9. Frons angular

10. Prothorax narrowed anteriorly

11. Anterolateral tubercle of pronotum not extending beyond anterior margin

12. Body broad

13. Elytral punctures of small or moderate size, not confused

14. Interstriae 9 strongly serrate
Derived

1. Mesal impression of vertex laterally margined by punctures

2. Elytra with eight striae

3. Eye small

4. Thin strip of cuticle at anterior margin of pronotum poorly formed

5. Ventral area of head reticulate

6. Red markings absent

7. Femora narrow

8. Interstriae 9 not strongly serrate

9. Frons not angular

10. Prothorax not narrowed anteriorly

11. Anterolateral tubercle of pronotum extending beyond anterior margin

12. Body narrow

13. Elytral punctures large, confused

14. Interstriae 9 not strongly serrate 
frons, the structure of the anterior margin of the pronotum, and the width of the hind femora. Genitalia structure was not found to be taxonomically helpful.

The findings of this study are that the physical appearance of most species of Microrhopala is extremely variable. Many clinal differences exist, some of which are usable in the characterization of geographical races. Also, tremendous variation often occurs among individuals in a local, interbreeding population. These variable characters include size, color, location and extent of colored markings, and, to a limited degree, density and coarseness of pronotal and elytral punctures. Because of this situation, it is difficult to select characters that are sufficiently reliable to separate taxa and, at the same time, constant within each taxon.

However, a few anatomical characters were found that not only allow for the identification of species but also suggest phylogenetic relationships.

One such character involves a thin, transparent piece of cuticle at the anterior margin of the pronotum. This structure is best seen in $M$. vittata, in which it forms the entire anterior margin of the pronotum. In other species this structure is obscure. However, it is always represented by either a small piece of cuticle that is present only mesally or by an indistinct, strongly scalloped piece of cuticle along the entire anterior margin of the pronotum. It is not reasonable to assume that this structure developed independently for each phylogenetic line of the genus. A more likely interpretation is that the well-formed structure of M. vittata is a primitive condition that has been variously reduced in other species.

Two other characters, a comparatively small eye and minute reticulation on the ventral area of the head, are also unique to $M$. vittata. These characters are not found in any other species of Microrhopala or in any other genera of the tribe Uroplatini.

Although most species of Microrhopala have distinct serrations on interstriae 9 of the elytra, these serrations have been greatly reduced or completely lost in several phylogenetic lines of the genus. Strong serrations are also prevalent in other genera of Uroplatini and are therefore considered to be ancestral. Also, the frons of most species is transversely, arcuately angulate or carinate. However, this apparently primitive character has been lost in a few species. Most species also have the hind femora slightly broadened. However, the hind femora of $M$. xerene, M. rubrolineata, and $M$. rileyi differ from the typical, apparently primitive condition in being more slender.

Another character involves the presence of red or orange vittae on the elytra. These vittae occur in M. vittata, M. xerene, M. rubrolineata, and $M$. rileyi, and also in the closely related genus Pentispa. They are here considered to be a primitive condition.

The elytral sculpture of Microrhopala differs tremendously from one species to another. However, the primitive condition apparently consists of regular strial rows that are separated by distinctly elevated interstriae. This condition exists for many of the species of this genus and is also prevalent throughout the tribe Uroplatini.

Microrhopala floridana is unusual in its very elongate form and in its parallel-sided prothorax. These characters are not found in any other species of the genus and are apparently derived from the more usual condition exhibited by other species.

\section{Phylogeny}

The morphological characters of Microrhopala suggest a major division in the phylogeny of the genus (Fig. 10). One branch includes a single species, $M$. vittata, which has several important characters. One such character is the anterior margin of the pronotum that is entirely formed by a slender, thin, transparent strip of cuticle. This strip is apparently a primitive structure that has been greatly reduced in other species. Also, the eye of $M$. vittata, in comparison to the size of the head, is much smaller, and interstriae 9 of the elytra is never serrate or conspicuously undulate. The second branch of the genus contains all other species.

This second branch can be divided into two species groups, the first of which includes $M$. xerene, $M$. rubrolineata, and $M$. rileyi. These species all have red or orange 
vittae on the pronotum or elytra or both, a character that they share with $M$. vittata. Also, the hind femora are distinctly broadened. Within the group, M. xerene is a distinctive species and is apparently only distantly related to $M$. rubrolineata and $M$. rileyi. It is distinct in having reduced serrations on interstriae 9 and in the angular frons. The two remaining species share many characters and appear to be closely related. Interestingly, some specimens of M. rubrolineata are remarkably similar to $M$. excavata cyanea. However, the characters listed above are sufficient to indicate that the species belongs with this group rather than with $M$. excavata.

The second species group includes M. excavata, M. hecate, M. erebus, and M. floridana. The distinctive species $M$. floridana exhibits a narrow body form and a parallel-sided prothorax. These substantial characters are unique in the genus and suggest significant phylogenetic distance between this species and others in the group. Two of the remaining species, M. excavata and M. hecate, show an interesting and slightly perplexing relationship. Microrhopala hecate is similar to $M$. e. excavata and differs from M. e. cyanea in having distinct elytral costae, but it is similar to M. e. cyanea and differs from M. e. excavata in having very regular strial rows and only slight serrations on interstriae 9 of the elytra. Although $M$. hecate is very distinctive in the structure of the frons, the above characters indicate a close affinity to M. excavata. The last species, $M$. erebus, is similar to $M$. excavata and $M$. hecate in its overall form but is very distinct in having extremely coarse, confused punctures on the elytra.

\section{Systematic Treatment}

\section{Genus Microrhopala Chevrolat}

Microrhopala Chevrolat, 1837, page 389 in Dejean, Catalogue des Coléoptères, $3 \mathrm{~d}$ ed. (Type species: Hispa vittata Fabricius, designated by Baly, 1864 , Ann. Mag. Nat. Hist. (3):14:268-269)

Diagnosis.- Within the tribe Uroplatini, Microrhopala differs from Brachycoryna and Stenopodius by the more elongate body, and by the antennae that exceed the length of the prothorax; from Octotoma and Glyphuroplata by having only eight elytral striae; and from the closely related Pentispa by having less strongly elevated elytral costae and by being more evenly convex dorsally.

Description.- Length 3.0-7.0 mm, 2.0-2.9 times as long as wide; color variable, either metallic blue, green, or bronze or nonmetallic red to black; pronotum and elytra sometimes marked with orange to red vittae.

Head subglobular, often with an arcuate, transverse carina below the antennae, a longitudinal carina between the antennae; surface minutely reticulate, at least dorsally; area surrounding eyes closely punctured; vertex mesally impressed, impression bordered on each side by a longitudinal row of punctures. Antennae distinctly longer than pronotum, segments 7-11 distinctly wider and more densely pubescent than preceding segments, segments 8-11 closely united and appearing as a single segment.

Pronotum 0.5-0.8 times as long as wide, widest posteriorly, often narrowed anteriorly, 0.6-0.9 times as wide as elytra at humeri; transverse profile convexly arched; in dorsal aspect, anterior margin appearing straight, lateral margins straight, arcuate, sinuate, or bisinuate, posterior margin bisinuate; anterolateral angles each armed by a bristle; surface usually minutely reticulate; punctation usually dense, of two or three sizes, smallest punctures equal in size to reticulations; a slender, usually slightly elevated strip lacking coarse punctures present in front of scutellum.

Elytra 1.6-2.2 times as long as wide, 0.7-0.8 times as long as body, usually slightly narrowed behind humeri, often minutely reticulate; eight striae and usually a scutellar striole present; striae 1 and 2 extending to apex of elytra, 8 and 9 separate or sometimes fused apically, extending to near suture where they join 1 and 2 ; interstriae 1 and 9 and also 3 and 7 meeting apically; interstriae 9 strongly elevated.

Venter, except mesal area of mesosternum, minutely reticulate; prosternum margined anteriorly by a row of short setae; abdomen sparsely punctate and pubescent, terminal segment more coarsely punctate and often more pubescent than preceding segments. 


\section{Key to the species and subspecies of Microrhopala}

1. Eyes small, separated from oral fossa by a distance equal to or greater than width of antennal segment 3 (Fig. 9a); interstriae 9 of elytra never serrate, not or but slightly undulate; anterior margin of pronotum formed by a thin, transparent, slender strip of cuticle; frons prominent, acutely, transversely carinate; impressions margining rugae on vertex shallow; interstriae 3 at least as wide as striae 2 or 3; red markings present on pronotum and elytra; British Columbia and Maine to California and Georgia; $5.0-7.0 \mathrm{~mm}$ vittata (Fabricius) Eyes large, separated from oral fossa by a distance less than width of antennal segment 3 (Figs. 9b-i); interstriae 9 undulate to serrate; thin cuticle on anterior margin of pronotum largely obsolete or strongly scalloped laterally; frons not carinate, sometimes angular; impressions margining rugae on vertex deeper; interstriae 3 often narrower; red markings present or absent

2(1). Red markings nearly always present on pronotum and elytra; hind femora not or but slightly broader than middle femora; striae 5 and 6 with apical punctures usually similar in size to those near base; strial row 2 usually with more than 20 punctures

Red markings never present on pronotum or elytra; hind femora conspicuously broader than middle femora; strial rows 5 and 6 with apical punctures usually larger than those near humerus; strial row 2 variable, often with less than 20 punctures

3(2). Interstriae 9 undulate to slightly serrate; lateral profile angled; tarsal segment 3 cleft ventrally to about half length of segment; eye margined behind by a double row of punctures (Fig. 9d); Alberta and Manitoba to Utah and Florida; $3.6-4.9 \mathrm{~mm}$ xerene (Newman)

Serrations on interstriae 9 conspicuous; lateral profile of frons not prominent or angulate; tarsal segment 3 cleft ventrally to about two-thirds length of segment; punctures behind eye arranged in a single row, less often confused or arranged in a double row .....

4(3). Scutellum about half as long as wide; eye margined behind by a double or strongly confused row of punctures (Fig. 9c); striae 7 and 8 united apically; Arkansas to Illinois; 4.1-5.8 mm rileyi Clark

Scutellum about two-thirds as long as wide; eye margined behind by a single or slightly confused row of punctures (Fig. 9b); striae 7 and 8 either fused or separate apically

5(4). Elytral vittae restricted to interstriae 5 or absent; dorsal surface usually minutely reticulate; striae 7 and 8 usually separate apically

Elytral markings occupying more than one interstriae or, if rarely absent, elytral reticulation obsolete; striae 7 and 8 often fused apically

6(5). Elytral vittae present; California and Arizona to Sonora and Durango; 3.7-5.4 $\mathrm{mm}$ rubrolineata rubrolineata (Mannerheim) Elytral vittae absent; California to Baja California; 3.7-5.4 mm rubrolineata signaticollis LeConte

7(5). Pronotal markings absent or greatly reduced; elytra distinctly reticulate; Arizona to New Mexico; 3.8-4.7 mm rubrolineata vulnerata Horn

Pronotal markings present, usually covering most of pronotum; minute reticulation of elytra absent or indistinct; California to Texas; $3.7-4.7 \mathrm{~mm}$ 
8(2). Prothorax strongly narrowed anteriorly; width across elytral humeri more than twice width across base of head; form usually stouter, 2.1-2.6 times as long as wide

Prothorax parallel sided or only slightly narrowed anteriorly; width across elytral humeri about twice that across base of head; form slender, 2.3-2.9 times as long as broad; Florida to North Carolina; $3.0-4.9 \mathrm{~mm}$ floridana Schwarz

9(8). Striae 2 with 11-25 punctures; interstriae 5 and 7 not or but slightly sinuate; serrations on interstriae 9 weaker, less numerous, sometimes largely obsolete, usually with one or fewer serrations per adjacent puncture

Striae 2 with 8-14 punctures; either interstriae 5 and 7 strongly sinuate, or punctures strongly confused and interstriae not evident; interstriae 9 strongly serrate, usually averaging more than one serration per adjacent puncture; Florida; 4.3-5.4 mm erebus (Newman)

10(9). Profile of frons prominently rounded, not angulate (Fig. 9g); interstriae not or only slightly sinuate; interstriae 5 distinctly elevated; striae 2 with 20-25 punctures; Ohio to South Carolina and Georgia; 4.1-5.5 mm .......... hecate (Newman) Profile of frons either not prominent or distinctly angulate; if interstriae 5 elevated, striae 2 with less than 20 punctures and lateral interstriae usually sinuate

11(10). Frons angulate in lateral aspect (Fig. 9f); interstriae 3 usually narrower than striae 3 or 4; interstriae 9 distinctly serrate; Minnesota and Nova Scotia to Texas and Florida; 4.1-5.6 mm ......................................... excavata excavata (Olivier)

Lateral profile of frons not angulate or prominent (Fig. 9e); interstriae 3 usually wider than striae 3 or 4 , at least posteriorly; interstriae 9 not or but slightly serrate; Alberta and Manitoba to Arizona, Texas, and Missouri; 4.0-6.0 $\mathrm{mm}$ excavata cyanea (Say)

\section{Microrhopala vittata (Fabricius)}

Hispa vittata Fabricius, 1798, Suppl. Ent. Syst., p. 117 (Lectotype, male; Carolina; Zoologisk Museum, Copenhagen, present designation)

Microrhopala vittata: Chevrolat, 1837, in Dejean, Catalogue des Coléoptères, 3d ed., p. 389.

Microrhopala laetula LeConte, 1859, Smithsonian Contribution to Knowledge 11:27-28 (Holotype, female?; "Kansas"; Mus. Comp. Zoology); Weise, 1911, Col. Cat. p. 38. Synonymy

Diagnosis.- This distinctive species can easily be recognized by the comparatively small eye that is separated from the oral fossa by a distance about equal to the width of antennal segment 3 and by the presence of a thin, slender, transparent strip of cuticle along the entire anterior margin of the pronotum. It is similar to $M$. xerene, M. rubrolineata, and M. rileyi in having red markings but is distinguished from them by the above characters as well as by the comparatively smaller strial punctures on the elytra.

MALE.- Length 5.0-6.0 mm, 2.0-2.4 times as long as wide; mature color red to black, each elytron with a lighter colored vitta.
Head with minute reticulation of dorsal surface continuing behind eyes and to ventral area; antennae usually black, occasionally rufous; front arcuately, transversely carinate below antennae; eyes comparatively small, separated from oral fossa by a distance equal to antennal segment 3; punctures bordering mesal impression of vertex comparatively shallow, usually confused.

Pronotum 0.6-0.7 times as long as wide, 0.8 times as wide as elytra across humeri, narrowed anteriorly; lateral margins rounded to sinuate; color orange to red, often with a median dark vitta; most punctures separated from one another by distances equal to more than the diameter of a puncture; entire anterior margin formed by a slender transparent strip of cuticle.

Elytra 1.7-1.8 times as long as wide, widest posteriorly; color red to black, interstriae 5 more lightly colored; surface minutely reticulate; strial punctures comparatively small, mostly separated from each other by distances at least equal to the diameter of a 


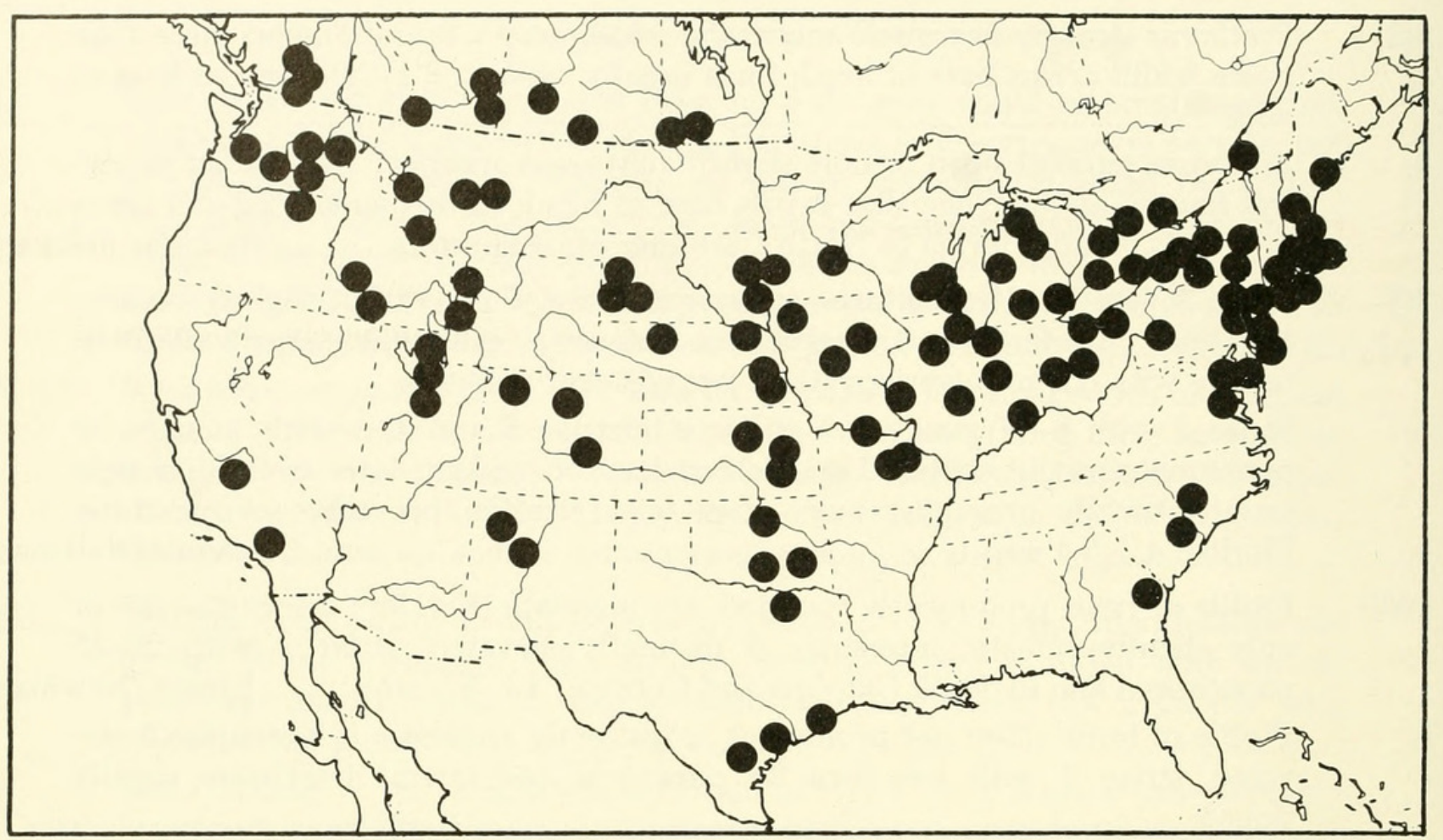

Fig. 1. Distribution of Microrhopala vittata.

puncture; interstriae 3 and 5 distinctly wider than others, slightly elevated; interstriae 9 never undulate or serrate.

Female.- Externally similar to male except usually larger, 5.5-7.0 mm long.

VARIATION.- Specimens from Georgia and South Carolina north to Quebec and eastern Ontario tend to be colored red with orange vittae on the elytra and to have comparatively rounder strial punctures, while more western specimens are usually black with red vittae, and the elytral punctures are slightly smaller and more elongate. Throughout the range, but especially from Ohio to Illinois and north to the Great Lakes, occur specimens with short vittae that do not occupy all of interstriae 5 , or vittae are rarely altogether lacking.

Distribution.- British Columbia and Maine to California, Texas, and Georgia (Fig. 1).

CANADA: Alberta: Cypress Hills, Elkwater Park, Manyberries, Medicine Hat, Robinson, Spring Pt., Sweetgrass, Twin Butte, Waterton Park. British Columbia: Cawston, Kamloops, Keremeos, Oliver, $7 \mathrm{mi} \mathrm{N}$ of Oliver, Vernon. Manitoba: Aweme, Baldur, Melita, Ninette. Ontario: Ad \& Lennox Co., Delhi, E. Moore L., Eramosa, Erieau, Fonthill, Grimsby, Guelph, Marmota, Niagara Falls, Ojibway, Penetanguishene, Port Dover, Prince Edward Co., St. Catharines, St. Thomas, Vineland, Windsor. Quebec: Beech Grove, Montreal. Saskatchewan: Aylesbury, Buffalo Pound, Swift Current, Kenosee, Minton, Rockglen, Val Marie, Wood Moun- tain. USA: California: Los Angeles Co., Tulare Co. Colorado: Boulder Co., Denver Co., Douglas Co., Larimer Co., Moffat Co., Pueblo Co., Routt Co., Yuma Co. Connecticut: Fairfield Co., Litchfield Co., Middlesex Co., New Haven Co. District of Columbia: Washington. Georgia: Chatham Co. Idaho: Ada Co., Bannock Co., Boise Co., Twin Falls Co. Illinois: Adams Co., Champaign Co., Cook Co., Knox Co., Lake Co., La Salle Co. Indiana: Clark Co., Lake Co., Lawrence Co., Tippecanoe Co., Warren Co. Iowa: Benton Co., Dickinson Co., Humboldt Co., Iowa Co., Lucas Co., Story Co. Kansas: Clay Co., Douglas Co., Greenwood Co., Shawnee Co. Maine: Lincoln Co. Maryland: Baltimore Co., Montgomery Co., Prince Georges Co., Baltimore. Massachusetts: Barnstable Co., Bristol Co., Essex Co., Hampden Co., Hampshire Co., Middlesex Co., Nantucket Co., Norfolk Co., Plymouth Co., Suffolk Co., Worcester Co. Michigan: Allegan Co., Cheboygan Co., Iosco Co., Jackson Co., Midland Co., Oakland Co., Oceana Co., Washtenaw Co., Wayne Co. Minnesota: Hennipin Co., Lincoln Co. Missouri: Boone Co., Callaway Co., Crawford Co., Gasconade Co., Hickory Co., Jefferson Co., Phelps Co., Pike Co., Randolph Co., Ste. Genevieve Co. Montana: Beaverhead Co., Cascade Co., Fergus Co., Judith Basin Co., Ravalli Co. Nebraska: Cherry Co., Douglas Co., Knox Co., Lancaster Co. New Hampshire: Belknap Co., Rockingham Co., Strafford Co. New Jersey: Bergen Co., Burlington Co., Camden Co., Cape May Co., Essex Co., Hudson Co., Monmouth Co., Ocean Co., Passaic Co., Union Co. New Mexico: Bernalillo Co., McKinley Co. New York: Albany Co., Allegheny Co., Bronx Co., Cattaraugus Co., Cayuga Co., Columbia Co., Dutchess Co., Erie Co., Genesee Co., Greene Co., Jefferson Co., Kings Co., Monroe Co., Nassau Co., Orange Co., Orleans Co., Oswego Co., Putnam Co., Queens Co., Rensselaer Co., Richmond Co., Rockland Co., Schuyler Co., Tompkins Co., Ulster Co., Wayne Co., Westchester Co., Wyoming Co. North 
Carolina: Gaston Co. Ohio: Ashtabula Co., Butler Co., Champaign Co., Clinton Co., Cuyahoga Co., Erie Co. Franklin Co., Lorain Co., Summit Co. Oklahoma: Murray Co., Pawnee Co., Payne Co., Pittsburg Co. Oregon: Umatilla Co. Pennsylvania: Allegheny Co., Delaware Co., Northampton Co., Philadelphia Co. Rhode Island: Kent Co., Washington Co. South Carolina: Florence Co. South Dakota: Brookings Co., Custer Co., Lawrence Co., Minnehaha Co., Pennington Co. Texas: Collins Co., Galveston Co., Goliad Co., Jim Wells Co., Victoria Co. Utah: Box Elder Co., Cache Co., Davis Co., Utah Co. Virginia: Arlington Co., Fairfax Co., Alexandria, Falls Church. Washington: Franklin Co., Grant Co., Pierce Co., Spokane Co., Yakima Co. Wisconsin: Calumet Co., Dodge Co., Milwaukee Co. Wyoming: Lincoln Co., Teton Co.

Biology.- This species has been reported from Solidago canadensis, S. graminifolia, S. juncea, S. missouriensis, S. mollis, S. sempervirens, Silphium laciniatum, and S. perfoliatum. Species of Solidago are apparently the preferred host. Adults are active from May to September.

Notes. - The above treatment was based on three syntypes of $H$. vittata in the Zoologisk Museum, Copenhagen, on the holotype of $M$. laetula, and on 2,275 other specimens. The three syntypes of $H$. vittata are mounted on the same pin; the top specimen, a male, is here designated as the lectotype for the species.

\section{Microrhopala xerene (Newman)}

Hispa xerene Newman, 1838, Ent. Mon. Mag. 5:390 (Lectotype, female; Trenton Falls, New York; British Mus. Nat. Hist., present designation)

Microrhopala xerene: Baly, 1864, Ann. Mag. Nat. Hist. (3) $14: 269$

Microrhopala xerene var. interrupta Couper, 1865, Canad. Nat. and Geol. 2:63 (Holotype, male?; Hermitage, north of Quebec); Weise, 1911, Col. Cat. p. 38. Synonymy

Diagnosis.- This species is similar to $M$. vittata, M. rubrolineata, and $M$. rileyi in having red markings. However, it is easily distinguished from $M$. vittata by having larger eyes that are separated from the oral fossa by less than the width of antennal segment 3 and by lacking a slender transparent strip of cuticle that is present along the entire anterior margin of the pronotum. It differs from $M$. rubrolineata in having interstriae 9 undulate or at most slightly serrate, in having the punctures behind the eye arranged in a strongly confused or double row, and in having the frons distinctly, transversely angled below the antennae. And it differs from $M$. rileyi by the smaller size, by lacking strong serrations on interstriae 9 , and by the distinctly angled frons.

MALE.- Length 3.6-4.6 mm, 2.2-2.5 times as long as wide; color black, marked with orange to red vittae laterally on the pronotum and on each elytron.

Head black, minutely reticulate dorsally, not reticulate laterally and ventrally; antennae black, distinctly reticulate; frons prominent, appearing angular in lateral aspect; mesal impression of vertex bordered laterally by a row of deep, contiguous punctures; eyes separated from oral fossa by less than width of antennal segment 3 ; punctures behind eye arranged in a double row or strongly confused.

Pronotum 0.6-0.7 times as long as wide, 0.7 times as wide as elytra at humeri, narrowed anteriorly; sides sinuate; color black, usually with orange or red vittae extending forward from near the base of striae 5 of the elytra to the anterior margin of the pronotum; anterior margin with a small, transparent, mesal piece of cuticle that is not developed laterally; punctation dense, deep, with most punctures separated by less than the diameter of a puncture.

Elytra 1.7-1.9 times as long as wide, widest posteriorly; color black, with interstriae 5 and the distal end of interstriae 3 orange to red; reticulation distinct; discal punctures of moderate size, separated from other punctures of the same row by the diameter of a puncture or slightly less; lateral punctures slightly larger, more closely spaced; striae 5 and 6 with apical punctures usually similar in size to basal punctures; interstriae 3 and 5 wider than other interstriae, slightly elevated distally; interstriae 9 undulate or weakly serrate.

Hind femora not or but slightly wider than middle femora.

Female.- Externally similar to male but averaging larger. $4.1-4.9 \mathrm{~mm}$ long.

VARiation.- A few specimens, most commonly from Virginia to Florida, have the orange or red markings of the pronotum expanded and covering most of the dorsal surface. However, many western specimens, from Alberta and Saskatchewan south to Utah and Colorado, entirely lack pronotal 


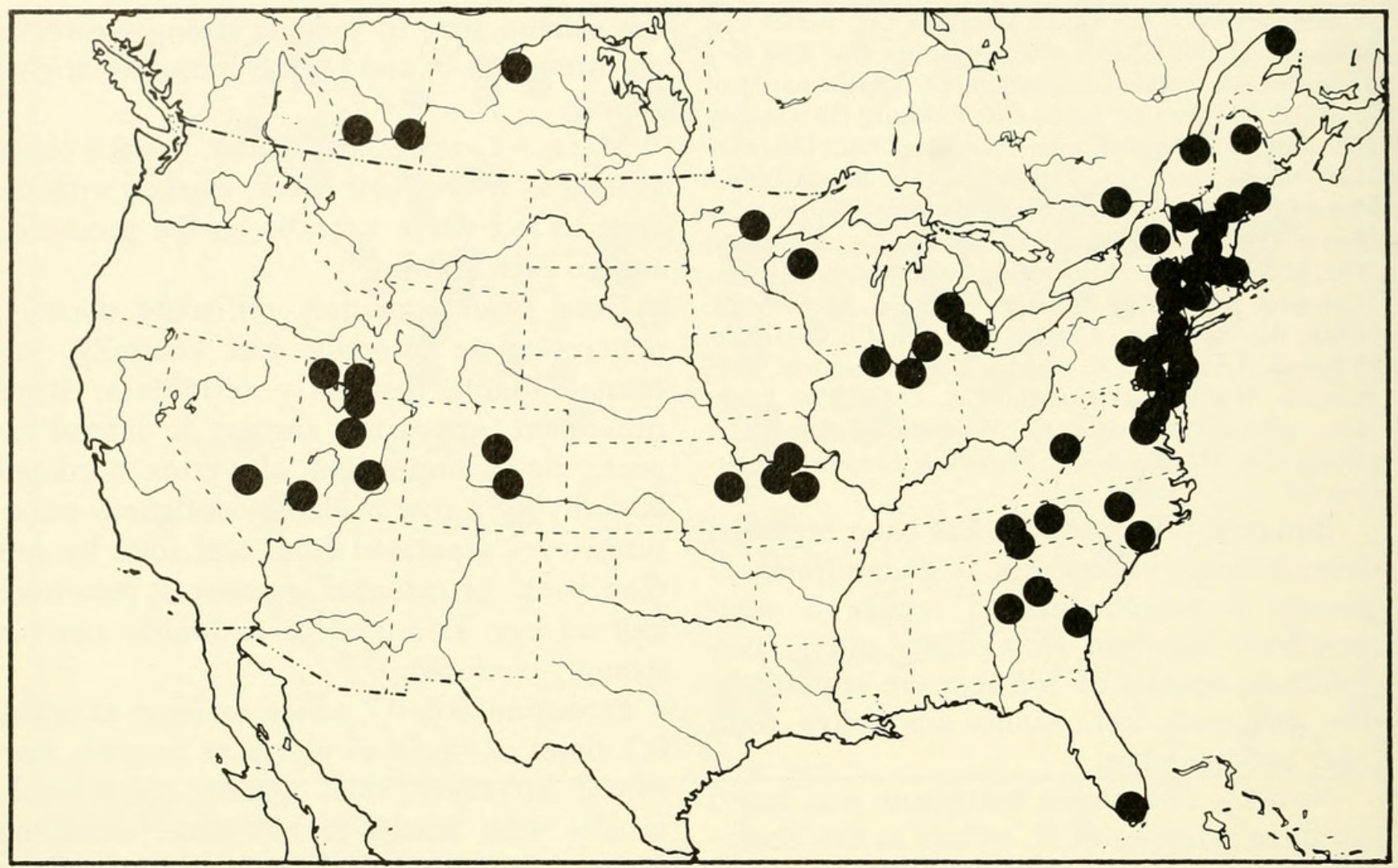

Fig. 2. Distribution of Microrhopala xerene.

markings. Throughout the range, but especially from Vermont to Maine and Quebec, specimens occur with interstriae 5 orange to red colored only in the basal half and at the distal end. And western specimens, from Alberta and Saskatchewan south to Utah and Colorado, have the elytral vittae expanded to include parts of interstriae 4 and 6 , a condition that is occasionally found to a lesser degree in the eastern part of the range.

Distribution.- Alberta and Maine to Utah and Florida (Fig. 2).

CANADA: Alberta: Elkwater Park, Lethbridge. Manitoba: Berens River. Ontario: Rainy R. Dist. Quebec: Cap Rouge, Duparquet, Gaspé, Gatineau Pk., Laniel, Ste-Foy, $25 \mathrm{mi}$ W of Gaspé. Saskatchewan: $8 \mathrm{mi}$ W of Paynton, Prince Albert. USA: Colorado: Denver Co., El Paso Co, Connecticut: Litchfield Co. District of Columbia: Washington. Florida: Monroe Co. Georgia: Chatham Co., Clarke Co., Fulton Co. Illinois: Cook Co. Indiana: La Porte Co., Porter Co. Kansas: Franklin Co. Maine: Lincoln Co., Oxford Co., Piscataquis Co. Maryland: Montgomery Co., Washington Co. Massachusetts: Berkshire Co., Hampden Co., Middlesex Co., Norfolk Co. Michigan: Berrien Co., Ingham Co., Jackson Co., Shiawassee Co., Washtenaw Co. Minnesota: Itasca Co. Missouri: Callaway Co., Pettis Co., Randolph Co. Nevada: Nye Co. New Hampshire: Cheshire Co., Grafton Co. New Jersey: Bergen Co., Burlington Co., Camden Co., Essey Co., Mercer Co., Morris Co., Warren Co. New York: Albany Co., Greene Co., Herkimer Co., Rockland Co., Sullivan Co., Ulster Co., Westchester Co. North Carolina: Brunswick Co., Buncombe Co., Guil- ford Co., Macon Co. Pennsylvania: Dauphin Co., Delaware Co., Lancaster Co., Montgomery Co., Philadelphia Co. Tennessee: Sevier Co. Utah: Box Elder Co., Cache Co., Utah Co., Washington Co., Wayne Co., Weber Co. Vermont: Lamoille Co. Virginia: Arlington Co., Fairfax Co., Stafford Co., Alexandria, Falls Church, Fredericksburg. West Virginia: Greenbrier Co. Wisconsin: Washburn Co.

Biology.- Reported host plants are Aster chilensis, A. cordifolius, A. patens, A. paternus, A. puniceus, Boltonia asteroides, Solidago caesia, S. canadensis, and S. juncea. Species of Aster are preferred to other hosts. In Provo Canyon, Utah, I have consistently encountered $M$. xerene feeding on A. chilensis, and, although Solidago canadensis is abundant in the same local area, the beetle does not utilize it. Adult beetles are most often collected from May to July.

Notes.- The above treatment was based on a syntype of Hispa xerene from Trenton Falls, New York, that is now in the British Museum (Natural History) and on 566 other specimens. This syntype is here designated as the lectotype of the species.

\section{Microrhopala rubrolineata (Mannerheim)}

Odontota rubrolineata Mannerheim, 1843, Soc. Imp. Nat. Moscou (Moskov. Obshch. Isp. Prirody Otd. 
Biol. Biul.) 2:307 (Holotype, male; Calif. bor. Universitets Zoologiska Museum, Helsinki) Microrhopala rubrolineata: Crotch, 1873, Proc. Acad. Nat. Sci. Philadelphia 25:82-83

Diagnosis.- This species is similar to $M$. rileyi, from which it differs by having the punctures behind the eye arranged in a single row that is not or only slightly confused. It differs from $M$. vittata and $M$. xerene, which are similarly marked with red or orange, by the frons that does not appear prominent, angled, or carinate in profile.

MALE.- Length 3.7-5.3 mm, 2.3-2.6 times as long as wide; color black, often with a metallic blue or purple cast, often with orange markings on the pronotum or elytra or both.

Head distinctly, minutely reticulate dorsally, not or obsoletely reticulate laterally and ventrally; frons not angulate or prominent; mesal impression of vertex bordered laterally by a deep row of contiguous punctures; eye separated from oral fossa by less than the width of antennal segment 3 ; punctures posterior to eye arranged in a single, sometimes slightly sinuate row, never strongly confused. Antennae black sometimes with a metallic blue, purple, or green cast.

Pronotum 0.5-0.8 times as long as wide, 0.6-0.9 times as wide as elytra at humeri, narrowed anteriorly; lateral margins usually appearing straight or bisinuate in dorsal aspect, less commonly sinuate or arcuate; anterior margin with a small, thin, mesal piece of cuticle that does not extend laterally; punctures deep, usually separated by the diameter of a puncture or less; orange markings sometimes present in lateral areas.

Elytra 1.7-2.0 times as long as wide, usually widest posteriorly; punctures deep, mostly separated by less than the diameter of a puncture; striae 5 and 6 with apical punctures usually similar in size to those near base; striae 2 with 20-29 punctures; interstriae 7 costate, at least distally; interstriae 9 distinctly serrate; color wholly dark, or variously marked with orange.

Hind femora not or but slightly wider than middle femora.

Female.- Externally similar to males from the same area but usually larger, $4.0-5.4 \mathrm{~mm}$ long.

Notes.- Four subspecies are recognized within this species.

\section{Microrhopala rubrolineata rubrolineata}

(Mannerheim)

Odontota rubrolineata Mannerheim, 1843, Soc. Imp. Nat. Moscou (Moskov. Obshch. Isp. Prirody Otd. Biol. Biul.) 2:307 (Holotype, male; Calif. bor.; Helsinki Museum)

Microrhopala rubrolineata: Crotch, 1873, Proc. Acad. Nat. Sci. Philadelphia 25:82-83.

Diagnosis.- This subspecies can be distinguished from the others by the orange elytral vittae that occupy all or most of interstriae 5 but are not expanded to other interstriae.

MALE.- Length 3.9-5.2 mm, 2.3-2.6 times as long as wide, prothorax and elytra with orange vittae.

Head black, sometimes with a metallic blue cast.

Pronotum 0.6-0.8 times as long as wide, $0.7-0.8$ times as wide as elytra at humeri; minute reticulation usually present, sometimes indistinct; lateral fourth orange except for narrow dark areas along the lateral margins and a slender dark area along the anterior margin; mesal area black, often with a metallic blue cast.

Elytra 1.7-2.0 times as long as wide; surface minutely reticulate; interstriae 3 and 5 usually wider than others; interstriae 5 and sometimes distal end of interstriae 3 orange, other areas black, sometimes with a metallic blue or purple cast.

Female.- Similar to male but averaging larger, 4.3-5.3 mm long.

Distribution.- Southern California and Arizona to Sonora and Durango (Fig. 3).

MEXICO: Durango: Durango. Sonora: $30 \mathrm{mi} \mathrm{N}$ Guayamas, $3 \mathrm{mi} \mathrm{N}$ Hermosillo. USA: Arizona: Cochise Co., Maricopa Co., Pima Co., Santa Cruz Co., Yuma Co. California: Almeda Co., Kern Co., Los Angeles Co., Madera Co., Orange Co., Riverside Co., San Bernardino Co., San Diego Co., Santa Clara Co., Ventura Co. Texas: Culberson Co.

Biology.- Reported host plants are Encelia californica, E. farinosa, Franseria acanthicarpa, F. ambrosioides, F. confertiflora, Haplopappus squarrosus, $H$. venetus, and Heterotheca grandiflora. Adults are active throughout the year but are most often collected during the summer.

Notes.- This subspecies freely interbreeds with M. r. militaris wherever the two populations contact each other in southern Arizona and southern California, and it freely interbreeds with $M$. $r$. signaticollis in southern 


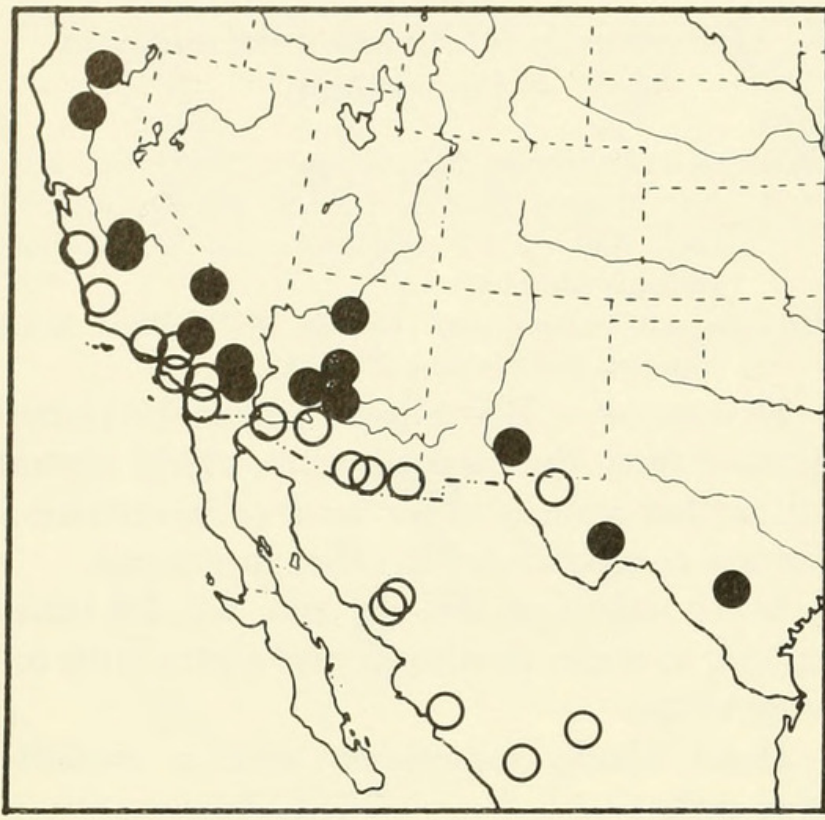

Fig. 3. Distribution of Microrhopala rubrolineata rubrolineata (open circles) and M. r. militaris (filled circles).

California. The above treatment was based on the holotype of Odontota rubrolineata and on 730 other specimens.

\section{Microrhopala rubrolineata signaticollis LeConte}

Microrhopala signaticollis LeConte, 1859, Proc. Acad Nat. Sci. Philadelphia 11:82 (Holotype, female?; Tejon, California; Mus. Comp. Zoology)

Microrhopala bivitticollis Baly, 1864, Ann. Mag. Nat. Hist. (3)14:268-271 (Holotype, female; probably California; British Museum); Weise, 1911, Col. Cat. p. 38. Synonymy

Diagnosis. - This subspecies can usually be recognized by the absence of elytral vittae. However, a few unusual specimens of $M$. $r$. militaris also lack elytral vittae. This subspecies differs from such unusual specimens by having distinct elytral reticulation. Also, a few specimens of M. $r$. signaticollis lack pronotal markings in addition to elytral markings and therefore resemble $M$. e. cyanea. Such specimens are most easily distinguished by the single row of punctures posterior to the eye.

MALE.- Length 3.7-5.2 mm, 2.4-2.6 times as long as wide; color black, often with a metallic blue or purple tint, usually with orange markings on the pronotum.

Head black, sometimes with a metallic blue cast.

Pronotum 0.5-0.7 times as long as wide, 0.6-0.9 times as wide as elytra at humeri; sur-

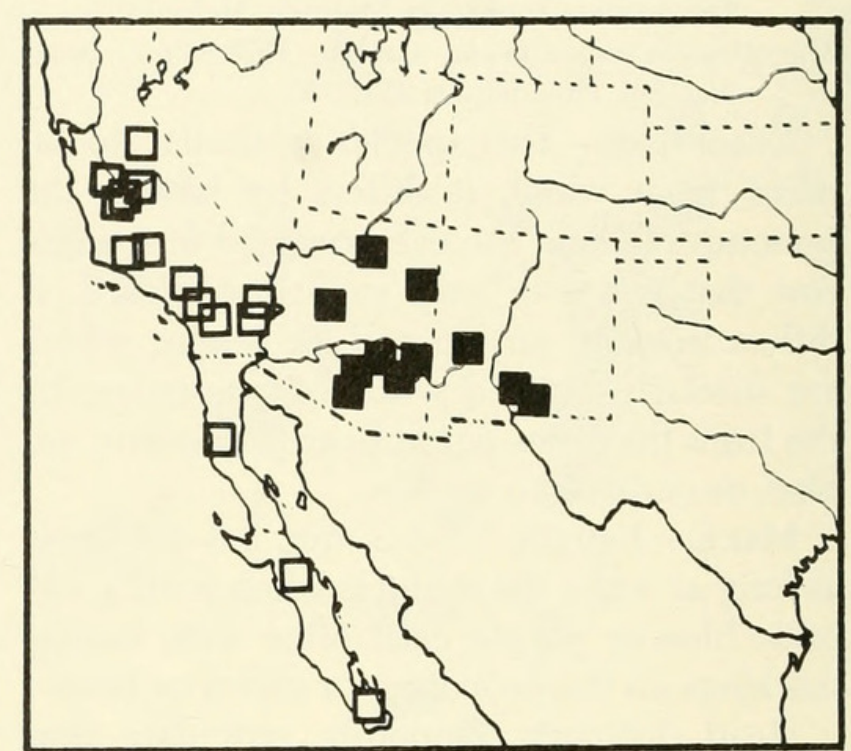

Fig. 4. Distribution of Microrhopala rubrolineata sig naticollis (open squares) and M. r. vulnerata (filled squares).

face minutely reticulate; color mostly black, often with a metallic blue tint; lateral fourth usually orange except a slender, dark area along the anterior margin and narrow dark areas along the lateral margins, or orange markings rarely absent.

Elytra 1.8-2.0 times as long as wide, distinctly, minutely reticulate; interstriae 3 slightly wider than others; colors black, often with a metallic blue or purple tint.

Female.- Externally similar to male but averaging larger, $4.0-5.4 \mathrm{~mm}$ long.

Distribution.- California to Baja California (Fig. 4).

MEXICO: Baja California del Norte: San Quintin, 10 mi S Catavina. Baja California del Sur: 5 mi W San Bartolo, Miraflores, $19 \mathrm{mi}$ E Rosario, Sierra La Laguna, Todos Santos. USA: California: Fresno Co., Kern Co., Los Angeles Co., Madera Co., Monterey Co., Orange Co., Riverside Co., San Bernardino Co., San Diego Co., Santa Barbara Co., Tulare Co., Tuolumne Co.

Biology.- This subspecies has been reported from Encelia californica, Haplopappus squarrosus, $H$. venetus, and Heterotheca grandiflora. Adults are active from April to August.

Notes.- This subspecies freely interbreeds with $M . r$. rubrolineata in areas of southern California where the populations contact each other. It also occasionally interbreeds with M. $r$. militaris in southeast California. The above treatment was based on the holotypes of $M$. signaticollis and M. bivitticollis and on 107 other specimens. 
Microrhopala rubrolineata vulnerata Horn

Microrhopala vulnerata Horn, 1883, Trans. Amer. Ent. Soc. 10:291-292 (Holotype, female?; Arizona; Mus. Comp. Zoology)

Microrhopala rubrolineata var. vulnerata: Weise, 1911, Col. Cat. 35:38.

Diagnosis.- The reduced or usually absent pronotal markings and the elytral markings that occupy more than a single interstriae distinguish this subspecies from others.

MALE.- Length 3.8-4.5 mm, 2.4-2.6 times as long as wide; color black or metallic blue, green, or purple, with orange markings on elytra.

Head black, often with a metallic blue or green cast.

Pronotum 0.6-0.8 times as long as wide, $0.7-0.8$ times as wide as elytra at humeri; reticulation distinct; color metallic blue or purple, orange markings absent or confined to posterolateral corners.

Elytra 1.8-1.9 times as long as wide; minute reticulation usually distinct; color mostly black, usually with a metallic blue or purple cast; orange markings present, usually confined to interstriae 5 basally, expanded behind humeri to interstriae 4 and 8 , narrowed distally and terminating between middle and distal fourth of elytra.

Female.- Externally similar to male but averaging larger, $4.2-4.7 \mathrm{~mm}$ long.

Distribution.- Arizona to New Mexico (Fig. 4).

USA: Arizona: Apache Co., Coconino Co., Gila Co., Graham Co., Greenlee Co., Pima Co., Pinal Co., Yavapai Co. New Mexico: Catron Co.

Biology.- This subspecies is known from Solidago sp. Adults are active from June to September.

Notes.- The above treatment was based on the holotype of $M$. vulnerata and on 23 other specimens.

\section{Microrhopala rubrolineata militaris Van Dyke}

Microrhopala rubrolineata var. militaris Van Dyke, 1925, Pan-Pacific Ent. 1:173 (Holotype, male, Siskiyou Co., California; California Acad. Sci.)

Diagnosis.- The well-developed pronotal markings in combination with the elytral markings that cover more than one interstriae usually distinguish this subspecies from others. However, a few unusual specimens are similar to $M$. $r$. signaticollis in lacking elytral markings. Such specimens are most easily recognized by the absence of distinct reticulation on the elytra.

MALE.- Length 3.7-4.6 mm, 2.3-2.4 times as long as wide; color black, sometimes with a slight metallic blue, green, or purple cast, with orange or sometimes red markings on the pronotum and elytra.

Head black, usually with a metallic blue or green tint.

Pronotum 0.6-0.7 times as long as wide, 0.7-0.8 times as wide as elytra at humeri; minute reticulation usually present, sometimes indistinct; mesal area and a slender area along the anterior margin black, often with a metallic blue or green tint; orange or sometimes red markings present in lateral areas, usually expanded to cover most of pronotum.

Elytra 1.7-1.8 times as long as wide; minute reticulation indistinct or lacking; color mostly black, often with a metallic blue or purple cast; orange or sometimes red markings present, usually confined to interstriae 5 basally, expanded to interstriae 8 and often to interstriae 4 behind humeri, narrowed distally, and terminating before middle of elytra.

Female.- Externally similar to male but averaging larger, $4.2-4.7 \mathrm{~mm}$ long.

\section{Distribution.-California to Texas (Fig.} $3)$.

USA: Arizona: Coconino Co., Maricopa Co., Pinal Co., Yavapai Co. California: Fresno Co., Imperial Co., Inyo Co., Los Angeles Co., Madera Co., Riverside Co., San Diego Co., Siskiyou Co. New Mexico: Otero Co. Texas: Brewster Co., Uvalde Co.

Biology.-Encelia farinosa and Franseria sp. are reported food plants. Adult beetles are active from March to September.

Notes.- This subspecies freely interbreeds with $M$. $r$. rubrolineata wherever the two populations contact each other in southern Arizona and southern California. It also occasionally interbreeds with $M$. $r$. signaticollis in southeastern California. The above treatment was based on the holotype of $M$. rubrolineata var. militaris and on 211 other specimens.

\section{Microrhopala rileyi, $\mathrm{n}$. sp.}

Diagnosis.- This species is most similar to M. rubrolineata, from which it differs by hav- 


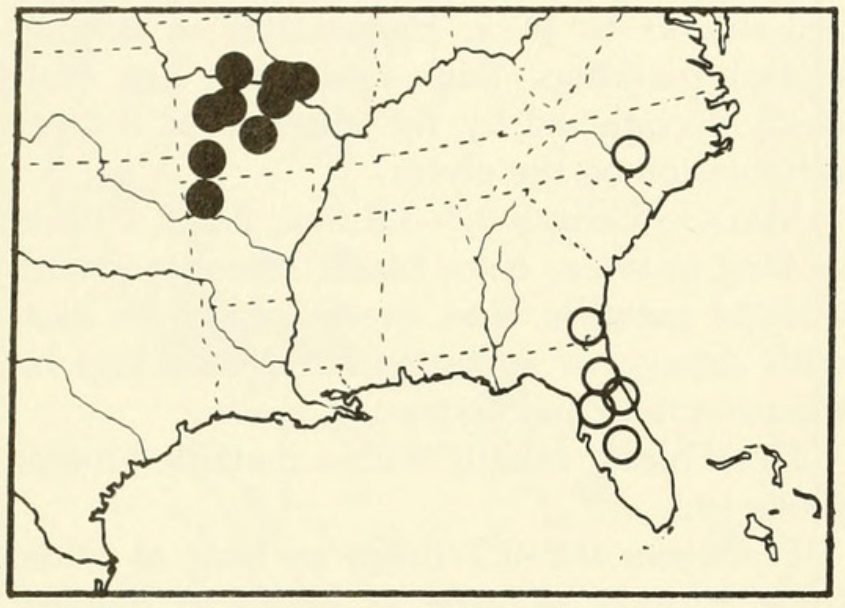

Fig. 5. Distribution of Microrhopala rileyi (filled circles) and M. floridana (open circles).

ing a double or strongly sinuate row of punctures behind the eye. It is also similar to $M$. vittata and $M$. xerene in having vittate elytra but differs from them by the frons that is not transversely carinate or angulate.

MALE.- Length 4.1-5.5 mm, 2.3-2.5 times as long as wide; mature color black, often with a metallic blue cast, with orange vittae on the prothorax and elytra.

Head distinctly reticulate dorsally, lacking reticulation laterally and ventrally; frons not appearing prominent or angulate in lateral aspect; mesal impression of vertex bordered laterally by a contiguous row of deep punctures; eye usually separated from oral fossa by less than width of antennal segment 3 , bordered posteriorly by a double or strongly sinuate row of punctures. Antennae black, sometimes with a slight metallic cast.

Pronotum 0.7-0.8 times as long as wide, 0.7-0.8 times as wide as elytra at humeri, narrowed anteriorly; color in mesal area dark, in lateral fourths orange; lateral margins appearing bisinuate in dorsal aspect; anterior margin with a small, thin, mesal piece of cuticle that is obsolete laterally; reticulation indistinct; punctures deep, mostly separated by less than the diameter of a puncture.

Scutellum usually only about half as long as wide.

Elytra 1.7-2.0 times as long as wide; reticulation indistinct; interstriae 3 and 5 slightly wider than others; interstriae 7 distinctly elevated; interstriae 9 serrate; punctures deep, mostly separated by less than the diameter of a puncture; striae 5 and 6 with apical punc- tures usually similar in size to those near base; orange markings occupying area from interstriae 3 to 8 basally, sometimes slightly narrowed, sometimes expanded to suture, narrowed distally and occupying only interstriae 5, usually extending to apex of interstriae 5, sometimes extending only to middle of elytra; distal end of interstriae 3 sometimes orange.

Hind femora not or but slightly wider than middle femora.

Female.-Externally similar to male but averaging larger, 5.2-5.8 $\mathrm{mm}$ long.

Distribution.-Arkansas to Illinois (Fig. 5).

Type material.- Holotype (male) U.S. National Museum number 100631, allotype (female), and one paratype: Randolph Bennett Wildlife Area, Randolph Co., Missouri, 31-V-1976, Helianthus sp., E. G. Riley, USNM. Paratypes: Springdale, Arkansas, 6VI-1932, California Acad. Sci. (1); Cahokia, Illinois, 31-V-1898, Univ. Missouri-Columbia (2); 4 miles NW of Warsaw, Benton Co., Missouri, 30-V-1970, E. G. Riley Collection (1); $1 / 2 \mathrm{mi} \mathrm{NE}$ jct. J on U.S. 54, Camden Co., Missouri, 25-VII-1975, E. G. Riley, E. G. Riley Collection (2); Gasconade Co., Missouri, 17VI-1971, D. D. Kopp, Univ. Missouri-Columbia (1); T37N, R26W, secs. 35 and 36, "Buzzards Roost," Doyal Township, St. Clair Co., Missouri, 12-V-1978, E. G. Riley, E. G. Riley Collection (2); Kimberling City, Stone Co., Missouri, 14-VI-1978, E. Riley, E. G. Riley Collection (1); Kimberling City, Stone Co., Missouri, 5-V-1979, E. G. Riley, E. G. Riley Collection (2); $3.5 \mathrm{mi} \mathrm{N}$ of Wappapello on Rt. 2, 11-VI-1975, E. G. Riley, E. G. Riley Collection (2); St. Louis, Missouri, 6-10-1932, Dr. Jass, USNM (1).

Biology.- This species has been found feeding on Helianthus sp. from May to July.

Notes. - The above treatment was based on the type series of 21 specimens. This species is named in honor of Edward G. Riley, Louisiana State University, who collected most of the type series.

\section{Microrhopala excavata (Olivier)}

Hispa excavata Olivier, 1808, Entomologie, ou histoire naturelle des insectes, avec leurs caractères génériques et spécifiques, leur description, leur 
synonymie, et leur figure enluminée. Coleopteres, vol. 6, p. 775 (Neotype, male; Montreal, Quebec; Canadian National Collection, present designation)

Microrhopala excavata: Dejean, 1837, Cat. Col. p. 389

Diagnosis.- This variable species can be distinguished from $M$. hecate by the lateral profile of the frons that is either distinctly angled (ssp. excavata) or arcuate and not prominent (ssp. cyanea), from $M$. erebus by the smaller elytral punctures that are not or only slightly confused, and from $M$. floridana by the stouter form and by the pronotum that is distinctly narrowed anteriorly.

MALE.- Length 4.0-5.6 mm, 2.2-2.4 times as long as wide; color black or metallic green, blue, or purple.

Head distinctly reticulate dorsally, not or indistinctly reticulate laterally and ventrally; mesal impression of vertex margined ląterally by a distinct row of deep, contiguous punctures; eye separated from oral fossa by less than the width of antennal segment 3 , bordered behind by contiguous punctures that are either strongly confused or arranged in a double row.

Pronotum 0.6-0.8 times as long as wide, 0.7-0.8 times as wide as elytra at humeri, narrowed anteriorly; lateral margins appearing arcuate, sinuate, bisinuate, or rarely straight; mesal area of anterior margin with a small, transparent piece of cuticle that does not extend laterally; surface usually minutely reticulate.

Elytra 1.6-1.9 times as long as wide, usually widest posteriorly; surface usually minutely reticulate; striae 2 with 11-25 punctures; striae 5 and 6 with apical punctures often slightly larger than basal punctures. femora.

Hind femora usually broader than middle

Female.- Externally similar to male but averaging larger, 4.6-6.6 $\mathrm{mm}$ long.

Notes.- This species can be divided into two subspecies.

\section{Microrhopala excavata excavata} (Olivier)

Hispa excavata Olivier, 1808, Entomologie, ou histoire naturelle des insectes, avec leurs caractères génériques et spécifiques, leur description, leur synonymie, et leur figure enluminée. Coleopteres, vol. 6, p. 775 (Neotype, male; Montreal,
Quebec; Canadian National Collection, present designation)

Microrhopala excavata: Dejean, 1837, Cat. Col. p. 389

Diagnosis.- This subspecies can be distinguished from M. e. cyanea by the more angular frons and by the distinctly elevated interstriae 5 .

MALE.- Length 4.1-5.3 mm, 2.2-2.4 times as long as wide; color black. Frons transversely, arcuately angled below antennae; mesal impression of vertex margined laterally by a contiguous row of deep punctures. Antennae usually metallic blue, sometimes black.

Pronotum 0.5-0.7 times as long as wide; surface minutely reticulate; punctures deep, closely, often contiguously spaced.

Elytra 1.6-1.9 times as long as wide; interstriae 7,5 , and often 3 elevated or, if costae indistinct, punctures somewhat confused and interstriae sinuate; interstriae 3 not or but slightly wider than other interstriae, not wider than striae 2 or 3 ; interstriae 9 distinctly serrate; punctures within each stria closely, usually contiguously spaced.

Female.- Externally similar to male but averaging larger, 4.8-5.6 $\mathrm{mm}$ long.

Variation.- Specimens from Pennsylvania and New Jersey to Maine and Quebec usually have slightly larger, more confused elytral punctures than do specimens from more southern areas.

Distribution.- Minnesota and Nova Scotia to Texas and Florida (Fig. 6).

CANADA: New Brunswick: Kouchibouguac N.P. Nova Scotia: Ingramport, Waverley. Ontario: Blackburn, Go Home Bay, Honey Harbor, Kanata, Orrville, Ottawa. Quebec: Beech Grove, Gatineau Pk., Georgeville, Montreal, Knowlton, Lucerne, Perkins Mills, Rigaud, St. Hyacinthe. USA: Alabama: Mobile Co. Connecticut: Fairfield Co., Litchfield Co. Florida: Escambia Co. Georgia: Hall Co. Illinois: Knox Co., Lake Co. Iowa: Woodbury Co. Kansas: Douglas Co. Louisiana: Natchitoches Parish. Maine: Androscoggin Co., Cumberland Co., Franklin Co., Hancock Co., Kennebec Co., Lincoln Co., Oxford Co., Washington Co., York Co. Maryland: Montgomery Co., Prince Georges Co., Baltimore. Massachusetts: Berkshire Co., Bristol Co., Hampshire Co., Middlesex Co., Norfolk Co., Worcester Co. Michigan: Jackson Co. Minnesota: Hennepin Co., Kanabec Co. Mississippi: George Co., Perry Co., Tishomingo Co. Missouri: St. Francois Co., Vernon Co. New Hampshire: Carrol Co., Cheshire Co., Coos Co., Grafton Co., Hillsborough Co. New Jersey: Atlantic Co., Bergen Co., Burlington Co., Camden Co., Essex Co., Gloucester Co., Middlesex Co., Union Co. New York: Bronx Co., Columbia Co., Essex Co., Greene Co., Nassau Co., Orange Co., Oswego Co., St. Lawrence Co., Sullivan Co., Tompkins 


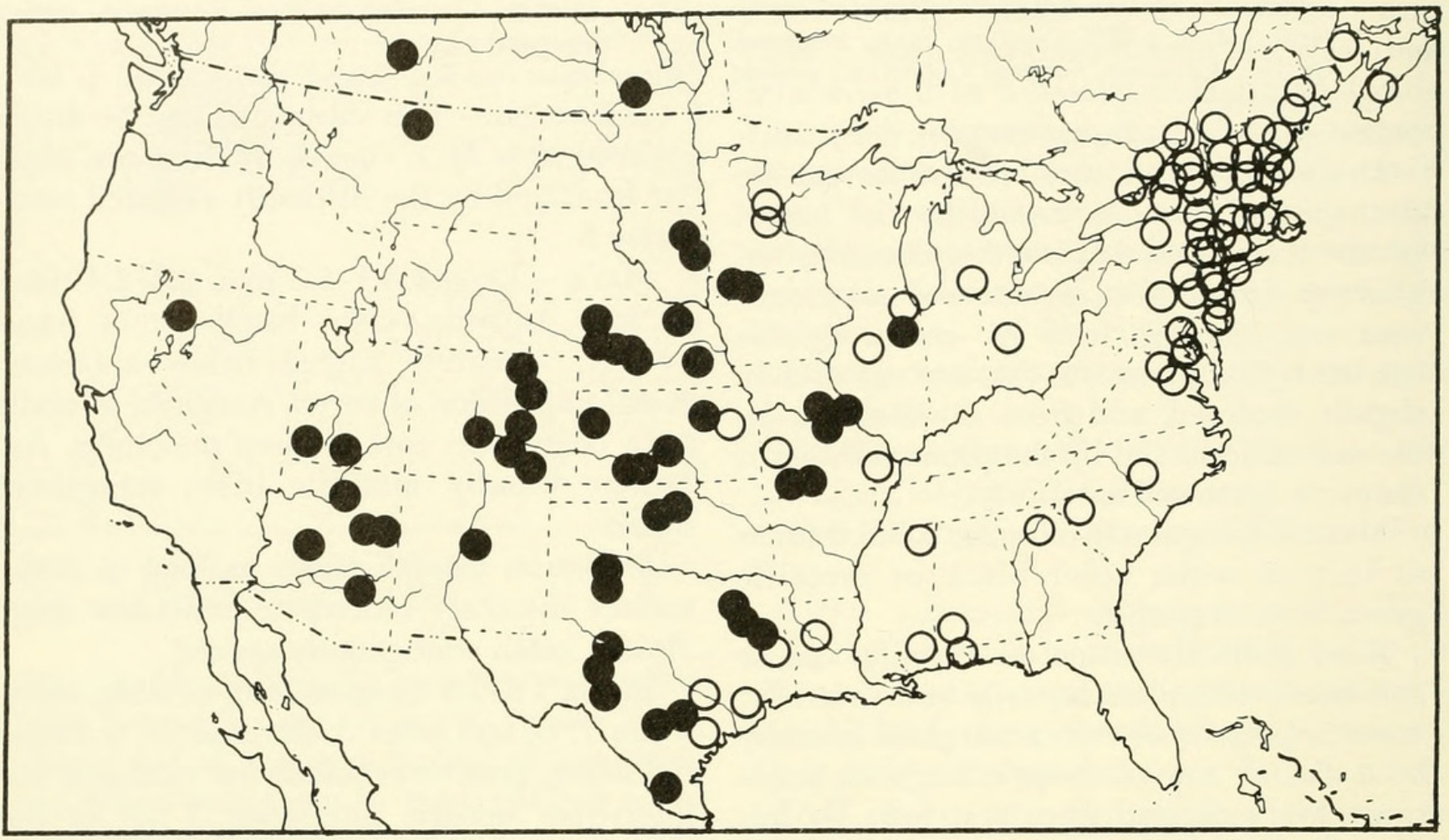

Fig. 6. Distribution of Microrhopala excavata excavata (open circles) and M. e. cyanea (filled circles).

Co., Ulster Co., Warren Co., Westchester Co. North Carolina: Moore Co. Ohio: Champaign Co. Pennsylvania: Berks Co., Dauphin Co., Monroe Co., Northampton Co., Pike Co. South Carolina: Oconee Co. Texas: Harris Co., Jasper Co., Lee Co., San Patricio Co. Vermont: Lamoille Co., Orleans Co., Washington Co. Virginia: Fairfax Co., Fredericksburg, Glencarlyn.

Biology.- This subspecies feeds on Doellingeria umbellata and Solidago sp. Most collections are made from May to September.

Notes. - The type of Hispa excavata has been lost from the Museum National d'Histoire Naturelle, Paris. However, a specimen from the Canadian National Collection is here designated as a neotype. This specimen is labeled Montreal, Quebec, 15-V-1979, A. Smetana and E. C. Becker. The above treatment was based on this neotype and on 345 other specimens.

\section{Microrhopala excavata cyanea (Say)}

Hispa cyanea Say, 1823, J. Acad. Nat. Sci. Philadelphia 3:433 (Neotype, male; Colorado Springs, Colorado; Museum of Comparative Zoology, present designation)

Microrhopala cyanea: Melsheimer, 1853, Cat. Desc. Col. U.S. p. 119

Diagnosis.- This subspecies differs from M. e. excavata by the frons that does not appear angular and by interstriae 5 that is not or but slightly elevated.
MALE.- Length 4.0-5.6 mm, 2.2-2.4 times as long as wide; color black or metallic green, blue, or purple.

Frons not prominent in lateral aspect, usually appearing arcuate; mesal impression of vertex margined laterally by a distinct row of deep, contiguous punctures. Antennae black.

Pronotum 0.6-0.8 times as long as wide; punctures deep, of three sizes, with coarse punctures mostly separated by less than the diameter of a puncture; surface usually minutely reticulate.

Elytra 1.7-1.9 times as long as wide; strial punctures in regular rows; interstriae straight or but slightly sinuate; interstriae 3 usually wider than striae 2 or 3 , wider than other interstriae; punctures within striae small to moderate in size, mostly separated by less than the diameter of a puncture; interstriae 7 usually elevated, 5 not or but slightly elevated, 3 not elevated; interstriae 9 weakly serrate.

Female. - Externally similar to male but usually larger than males from the same area, $4.6-6.0 \mathrm{~mm}$ long.

VARIATION.- Although color is not strictly correlated with locality, black, nonmetallic specimens tend to be collected from Nebraska and Kansas east to Illinois and from Manitoba, and metallic specimens tend to occur in other areas of the range. Metallic blue and 
purple colors are common in South Dakota and Iowa, and metallic green beetles are usually found from Utah and Arizona to Texas. Specimens south of central Colorado and Kansas usually have slightly larger elytral punctures that are round and gradually impressed, and more northern beetles have slightly smaller punctures that are abruptly impressed and often elongate. Specimens from Manitoba are small and have indistinct reticulation on the pronotum, and interstriae 7 is not elevated.

Distribution.- Alberta and Manitoba to Arizona, Texas, and Missouri (Fig. 6).

CANADA: Alberta: Laggan, Medicine Hat, Mill Creek Road to Big Bear. Manitoba: Aweme, Treesbank. USA: Arizona: Apache Co., Coconino Co., Gila Co., Navajo Co., Yavapai Co. Colorado: Chaffee Co., El Paso Co., Huerfano Co., Las Animas Co., Morgan Co., Weld Co. Illinois: Cook Co. Iowa: Dickinson Co., Emmet Co. Kansas: Clark Co., Meade Co., Reno Co., Riley Co., Wallace Co. Missouri: Barry Co., Boone Co., Gasconade Co., Taney Co. Montana: Hill Co. Nebraska: Cherry Co., Custer Co., Knox Co., Lancaster Co. Nevada: Washoe Co. New Mexico: Santa Fe Co. Oklahoma: Alfalfa Co., Major Co. South Dakota: Brookings Co., Codington Co. Texas: Caldwell Co., Cherokee Co., Comal Co., Dickens Co., Gillespie Co., Hidalgo Co., Motley Co., Sabine Co., Tarrant Co., Uvalde Co., Val Verde Co. Utah: Kane Co., Washington Co.

Biology.-Helianthus sp. has been reported as the host plant. Adults are most often collected from May to September.

Notes.- The appearance of these beetles is very different from that of M. e. excavata, and the two subspecies have traditionally been considered distinct species. However, the two populations freely interbreed wherever they contact each other and must be considered conspecific. A specimen in the Museum of Comparative Zoology is labeled Colo. Spr., Colorado, 6,000-7,000 ft, June $15-30$, '96, H. F. Wickham. This specimen is here designated as the neotype of Hispa cyanea. The above treatment was based on this neotype, on 5 specimens from the LeConte collection, and on 302 other specimens.

\section{Microrhopala hecate (Newman)}

Hispa hecate Newman, 1841, Entomologist 1:77 (Holotype, male, Warm Springs, North Carolina; British Mus. Nat. Hist.)

Diagnosis.- This species is similar to $M$. excavata. However, the very prominent but not angled frons, the regular strial rows, the distinctly elevated interstriae 5 and usually interstriae 3 , and the undulate or but slightly serrate interstriae 9 are sufficient characters for correct identification.

MALE.- Length 4.1-4.9 mm, 2.2-2.6 times as long as wide; color black, usually with a slight metallic red cast on the elytra and pronotum, a metallic green cast often on the floor of the punctures.

Head minutely reticulate dorsally, lacking reticulation laterally and ventrally; frons very prominent in lateral aspect, not angulate; mesal impression of vertex margined laterally by a contiguous row of deep punctures; eye separated from oral fossa by a distance less than the width of antennal segment 3 , bordered posteriorly by contiguous punctures that are not arranged in a single row. Antennae metallic green, blue, or purple.

Pronotum 0.6-0.8 times as long as wide, 0.7-0.8 times as wide as elytra; lateral margins usually appearing bisinuate in dorsal aspect; anterior margin with a small, thin, mesal piece of cuticle that is obsolete laterally; punctures deep, separated by less than the diameter of a puncture.

Elytra 1.7-1.8 times as long as wide, widest posteriorly; reticulation distinct; interstriae 9 undulate or but slightly serrate; interstriae 7,5 , and often 3 distinctly elevated, costate; interstriae 2 and 3 wider than others; punctures deep, mostly contiguously spaced within each row; striae 2 with 11-25 punctures; striae 5 and 6 with apical punctures often larger than basal punctures.

Hind femora usually wider than middle femora.

Female.- Externally similar to male but larger, 4.2-5.5 mm long.

Distribution.- Ohio to South Carolina and Georgia (Fig. 7).

USA: Georgia: Fulton Co., Rabun Co. North Carolina: Buncombe co., Macon Co., Moore Co., Transylvania Co. Ohio: Scioto Co. South Carolina: Oconee Co. West Virginia: Greenbrier Co.

Biology.- The food plant of this species is unknown. However, adults have been collected from April to August.

Notes.- This species was placed in synonymy with $M$. cyanea by Gemminger and Harold (1876). The color, shape of the frons, and nature of the elytral punctation readily 


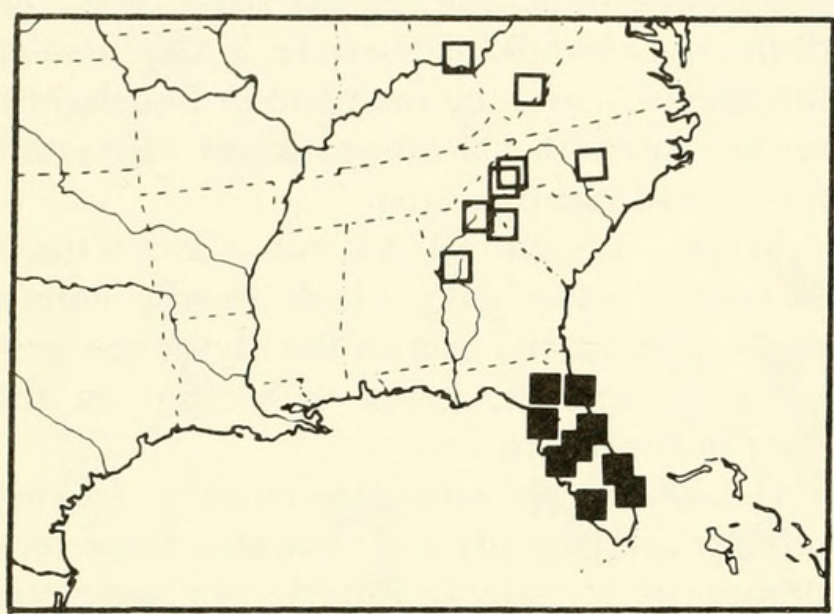

Fig. 7. Distribution of Microrhopala hecate (open squares) and $M$. erebus (filled squares).

distinguish the two species, however. The above treatment was based on the holotype of Hispa hecate and on 25 other specimens.

\section{Microrhopala erebus (Newman)}

Hispa erebus Newman, 1841, Entomologist 1:77 (Lectotype, female, St. Johns Bluff, Florida; British Mus. Nat. Hist., present designation)

Microrhopala erebus: Schwarz, 1878, Proc. Amer. Philos. Soc. Philadelphia 18:369

Diagnosis.- This species differs from others in the genus by the very coarse sculpture of the elytra. The punctures are large and contiguous or often confluent, and the interstriae, especially laterally, are indistinguishable or at least strongly sinuate.

MaLE.- Length 4.3-5.2 mm, 2.1-2.4 times as long as wide; mature color black; sculpture coarse.

Head minutely reticulate dorsally, not or indistinctly reticulate laterally and ventrally; frons prominent, transversely, arcuately angled; mesal impression of vertex margined laterally by a row of deep, contiguous punctures; eye separated from oral fossa by a distance less than the width of antennal segment 3 , margined posteriorly by contiguous, confused punctures. Antennae black, sometimes with a metallic blue cast.

Pronotum 0.6-0.8 times as long as wide, 0.7-0.8 times as wide as elytra at humeri; anterior margin with a small, thin, mesal piece of cuticle that does not extend laterally; lateral margins usually appearing bisinuate in dorsal aspect, sometimes sinuate or arcuate; surface minutely reticulate; punctures deep, mostly large, contiguous.

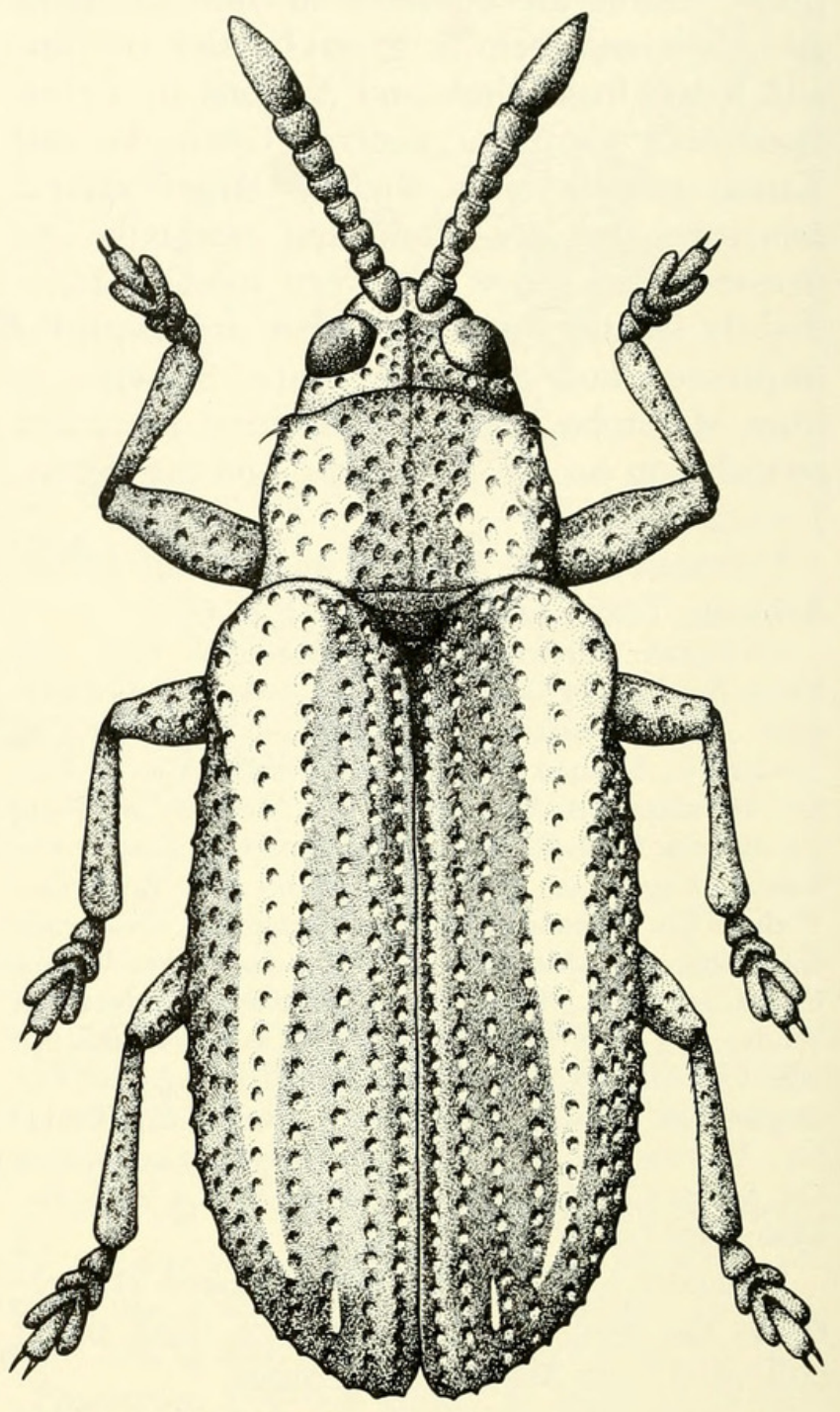

Fig. 8. Microrhopala rileyi.

Elytra 1.6-1.8 times as long as wide, usually slightly narrowed behind humeri, widest posteriorly; minute reticulation present, sometimes weak; punctures large, laterally and usually dorsally confused; striae 2 with 8-14 punctures; striae 5 and 6 with apical punctures often larger than basal punctures; most interstriae, especially in lateral areas, strongly sinuate or indistinguishable; interstriae 9 strongly serrate.

Hind femora usually wider than middle femora.

Female.- Externally similar to male but averaging larger, 4.5-5.4 $\mathrm{mm}$ long.

Distribution.-Florida (Fig. 7).

USA: Florida: Alachua Co., Lake Co., Lee Co., Levy Co., Manatee Co., Orange Co., Osceola Co., Palm Beach Co., Pinellas Co., Polk Co., Putnam Co., St. Johns Co., Seminole Co., Sumpter Co., Volusia Co.

Biology.- This species is known from Solidago sp. and is most abundantly collected from March to May. 

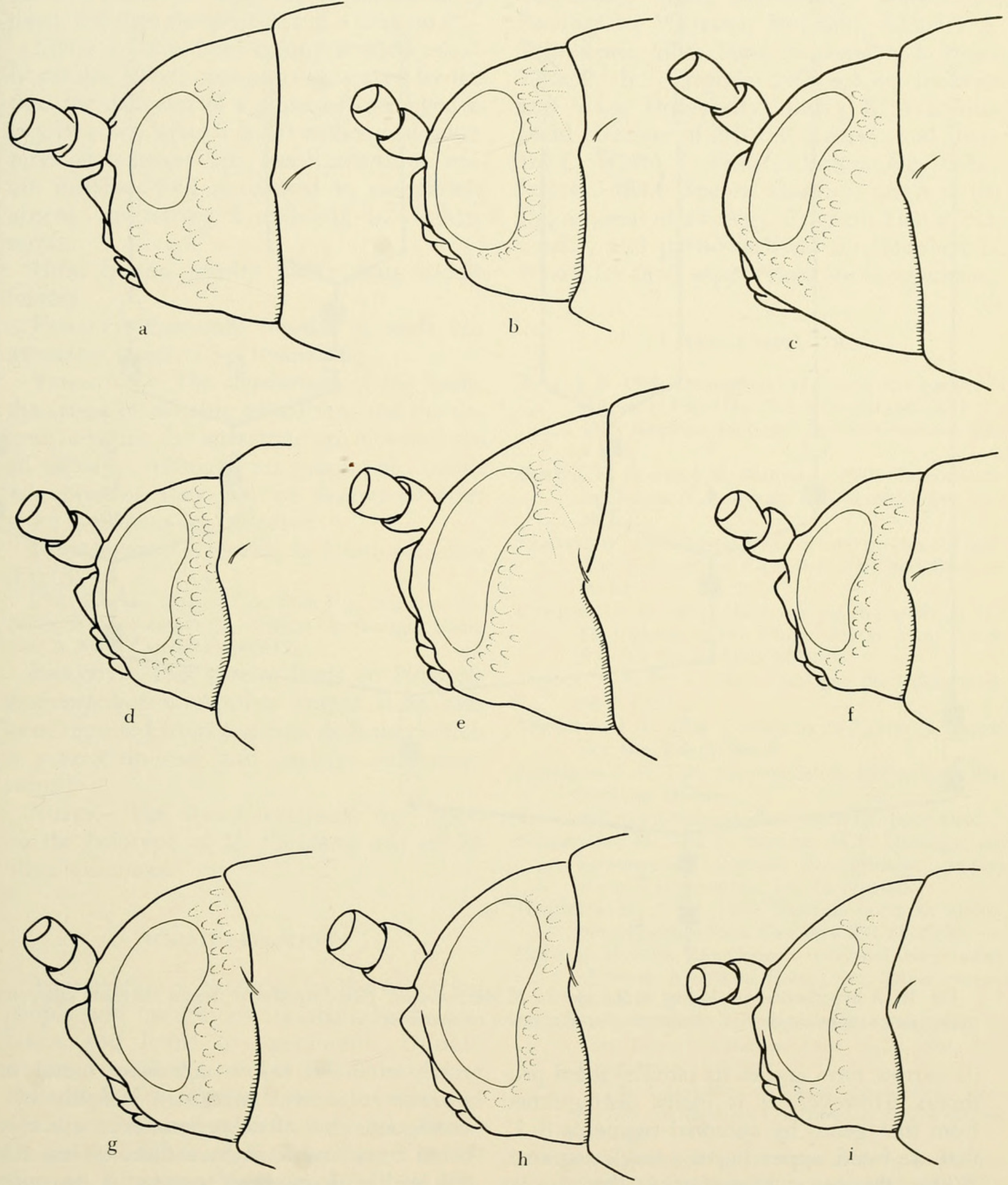

Fig. 9. Heads of Microrhopala spp.: (a) M. vittata, (b) M. rubrolineata, (c) M. rileyi, (d) M. xerene, (e) M. excavata cyanea, (f) M. e. excavata, (g) M. hecate, (h) M. erebus, (i) M. floridana.

Notes.- The above treatment was based on two syntypes of Hispa erebus from the British Museum and on 114 other specimens. The female syntype labeled Ent. Club 44-12 is here designated as the lectotype for the species.

\section{Microrhopala floridana Schwarz}

Microrhopala floridana Schwarz, 1878, Proc. Amer. Philos. Soc. Philadelphia 17:369 (Holotype, male, Sumpter Co., Florida; USNM)

Diagnosis.- This species superficially resembles members of the genus Anisostena in 


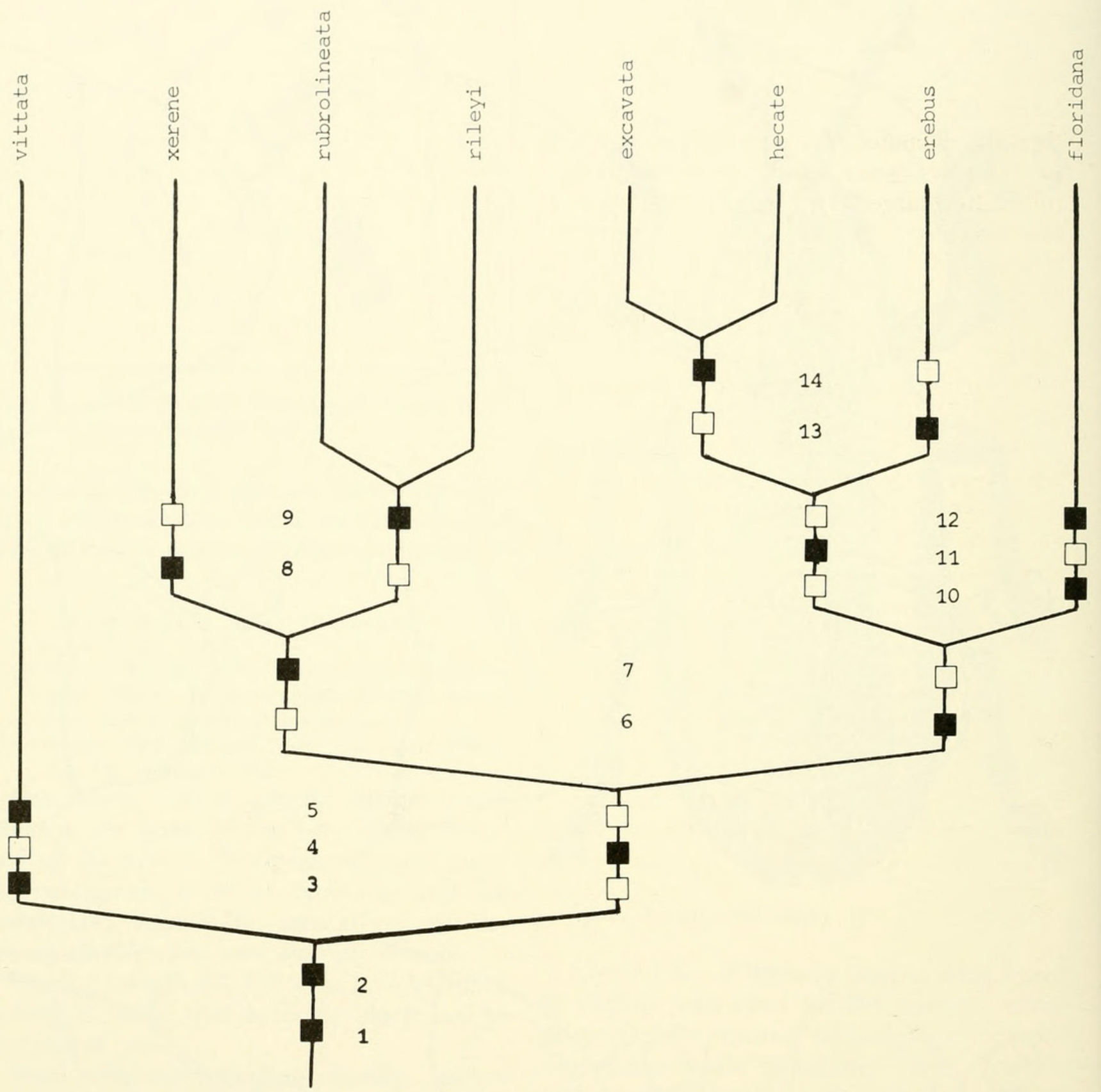

Fig. 10. A hypothetical phylogeny of the species of Microrhopala. Filled squares represent ancestral characters; open squares represent derived characters. Numbers refer to characters in Table 1.

its narrow form and in its parallel-sided prothorax. However, it is easily distinguished from that genus by antennal segments 8-11 that are fused, appearing as a single segment. Within the genus Microrhopala this species most closely resembles $M$. excavata, from which it differs by the more slender form and the parallel-sided prothorax.

MALE.- Length 3.4-4.5 mm, 2.3-2.9 times as long as wide; color black or less commonly metallic blue.

Head distinctly reticulate dorsally, not or indistinctly reticulate laterally and ventrally; frons arcuately, transversely angled or nar- rowly rounded below antennae; mesal impression of vertex margined laterally by a contiguous row of deep punctures; eye separated from oral fossa by a distance less than the width of antennal segment 3, margined behind by contiguous, confused punctures. Antennae black, sometimes with a metallic blue tint.

Pronotum 0.7-0.8 times as long as wide, 0.7-0.9 times as wide as elytra at humeri, not or but slightly narrowed anteriorly; lateral margins appearing arcuate, sinuate, or bisinuate in lateral aspect; anterior margin with a small, thin, mesal piece of cuticle that 
does not extend laterally; minute reticulation distinct; punctures deep, mostly separated by much less than the diameter of a puncture.

Elytra 1.7-2.2 times as long as wide, usually parallel sided; punctures separated by less than the diameter of a puncture, arranged in regular rows; striae 5 and 6 with apical punctures often larger than basal punctures; costae variable, well developed to completely absent; interstriae 9 undulate to slightly serrate.

Hind femora usually wider than middle femora.

Female.-Externally similar to male but averaging larger, 3.8-4.9 $\mathrm{mm}$ long.

VARIATION.- The slenderness of the body, the extent of metallic coloration, and the degree to which the interstriae are elevated are all variable. Although no geographic trends are apparent, they may be discovered after more specimens are collected.

Distribution.-Florida to North Carolina (Fig. 5).

USA: Florida: Marion Co., Polk Co., Putnam Co., Seminole Co., Sumpter Co., Volusia Co. Georgia: Chariton Co. North Carolina: Moore Co.

Biology.- This species feeds on Pityopsis graminifolia from April to August. It has also been reported from Lupinus diffusus, which is a very unusual and perhaps erroneous record.

Notes.- The above treatment was based on the holotype of $M$. floridana and on 25 other specimens.

\section{ACKNOWLEDGMENTS}

Appreciation is extended to the following people and institutions for their kind assistance and loans of specimens: Donald Azuma, Academy of Natural Sciences of Philadelphia; Nicole Berti, Museum National d'Histoire Naturelle, Paris; Robert L. Blinn, University of Missouri-Columbia; Lee $\mathrm{H}$. Herman, American Museum of Natural History; Charles L. Hogue, Los Angeles County Museum of Natural History; David H. Kavanaugh, California Academy of Sciences; L. L. Pechuman, Cornell University; Laurent LeSage, Canadian National Collection; Ole Martin, Zoologisk Museum, Copenhagen; Alfred F. Newton, Jr., Museum of Comparative Zoology; Carl A. Olson, University of Arizona; R. D. Pope, British Museum (Natural
History); Edward G. Riley, Louisiana State University; Hans Silfverberg, Universitets Zoologiska Museum, Helsinki; Charles A. Triplehorn, Ohio State University; J. Reese Voshell, Jr., Virginia Polytechnic Institute and State University; Larry E. Watrous, Field Museum of Natural History; and Richard E. White, Systematic Entomology Laboratory, USDA. Special thanks is given to the Department of Zoology, Brigham Young University, and particularly to Dr. Stephen L. Wood, for their support and encouragement.

\section{Literature Cited}

BALY, J. S. 1864. Descriptions of genera and species of Hispinae. Ann. Mag. Nat. Hist. (3)14:261-271.

1885. Hispidae. Biologia Centrali-Americana 6(2): $1-124$.

Barber, H. S., and J. C. Bridwell. 1940. Dejean Cataloge names (Coleoptera). Bull. Brooklyn Ent. Soc. $35: 1-12$.

Couper, W. 1865. Descriptions of new species of Canadian Coleoptera. Canadian Nat. and Geol. 2: 60-63.

Crotch, G. R. 1873. Materials for the study of the Phytophaga of the United States. Proc. Acad. Nat. Sci. Philadelphia 25:19-83.

Dejean, P. F. M. A. 1837. Catalogue des Coléoptères, ed. 3. Paris.

Douglass, J. R. 1929. Coleoptera of Kansas. J. Kansas Ent. Soc. 2:1-15, 26-38.

FABricius, J. C. 1798. Supplementum Entomologia Systematica. Hafniae.

Systema eleutheratorum, vol. 2, 687 pp. Kiliae.

Gemminger, M., and E. Harold. 1876. Catalogus coleopterorum hucusque descriptorum synonymicus et systematicus, vol. 12. Munich.

Hendrickson, G. O. 1930. Biologic notes on Microrhopala vittata Fabr. Canadian Ent. 62:98-99.

Hons, G. H. 1883. Miscellaneous notes and short studies of North American Coleoptera. Trans. Amer. Ent. Soc. 10:269-312.

LeConte, J. L. 1859a. Catalogue of the Coleoptera of Fort Tejon, California. Proc. Acad. Nat. Sci. Philadelphia 11:69-90.

1859b. Coleoptera of Kansas and eastern New Mexico. Smithsonian Contribution to Knowledge $11: 1-58$.

McCauley, R. H. 1938. A revision of the genus Microrhopala in North America, north of Mexico. Bull. Brooklyn Ent. Soc. 33:145-169.

Mannerheim, C. G. v. 1843. Beitrag zur Käferfauna der Aleutischen Inseln, der Insel Sitka und Neu-Californiens. Soc. Imp. Nat. Moscou (Moskov. Obshch. Isp. Prirody Otd. Biol. Biul.) 16:175-314.

Melsheimer, F. V. 1846. Descriptions of new species of Coleoptera of the United States. Proc. Acad. Nat. Sci. Philadelphia 3:158-181.

1853. Catalogue of the described Coleoptera of the United States. Smithsonian Institution, Washington. 
Newman, E. 1838. Entomological notes. Ent. Mon. Mag. 5:372-402.

1841. Entomological notes. Entomologist 1: 73-78.

Olivier, A. G. 1808. Entomologie, ou histoire naturelle des insectes, avec leurs caractères génériques et spécifiques, leur description, leur synonymie, et leur figure enluminée. Coleopteres, vol. 6. Paris.

SAY, T. 1823. Descriptions of coleopterous insects collected in the late expedition to the Rocky Mountains, performed by order of Mr. Calhoun, secretary of war, under the command of Major Long. J. Acad. Nat. Sci. Philadelphia 3:403-462.
SCHAEFFER, C. F. A. 1906. On new and known genera and species of the family Chrysomelidae. Mus. Brooklyn Inst. Sci. Bull. 1:221-253.

Schwarz, E. A. 1878. The Coleoptera of Florida. Proc. Amer. Philo. Soc. Philadelphia 17:353-471.

Sмiтh, J. B. 1885. Some new species of Hispini. Entomologia Americana 1:94.

VAN DyKe, E. C. 1925. Notes and descriptions of new species of west American Hispinae. Pan-Pacific Ent. 1:170-173.

Weise, J. 1910. Beitrag zur Kenntnis der amerikanische Hispinen. Arch. Naturg. 76:67-127.

1911. Coleopterorum catalogus, chrysomelidae; Hispinae 35:1-94. 


\section{$2 \mathrm{BHL}$ Biodiversity Heritage Library}

1983. "A revision of the genus Microrhopala (Coleoptera: Chrysomelidae) in America north of Mexico." The Great Basin naturalist 43, 597-618. https://doi.org/10.5962/bhl.part.4488.

View This Item Online: https://www.biodiversitylibrary.org/item/35769

DOI: https://doi.org/10.5962/bhl.part.4488

Permalink: https://www.biodiversitylibrary.org/partpdf/4488

\section{Holding Institution}

Harvard University, Museum of Comparative Zoology, Ernst Mayr Library

\section{Sponsored by}

Harvard University, Museum of Comparative Zoology, Ernst Mayr Library

\section{Copyright \& Reuse}

Copyright Status: In copyright. Digitized with the permission of the rights holder.

License: http://creativecommons.org/licenses/by-nc-sa/3.0/

Rights: https://biodiversitylibrary.org/permissions

This document was created from content at the Biodiversity Heritage Library, the world's largest open access digital library for biodiversity literature and archives. Visit BHL at https://www.biodiversitylibrary.org. 